\title{
COR DE JAMBO E OUTROS MATIZES AMAZÔNICOS: SOBRE A ABOLIÇÃO DA MULATA E O ADVENTO DA MORENA CHEIROSA NAS FESTAS JUNINAS DE BELÉM
}

Rafael da Silva Noleto ${ }^{1}$

${ }^{1}$ Universidade Federal de Pelotas, Pelotas/RS, Brasil

\section{Apresentando}

Como pensar na atuação consciente do Estado em termos de políticas públicas para a promoção das culturas populares, no sentido de produzir categorias sociais que sexualizam a raça e racializam o gênero? Com esta pergunta em mente, este artigo visa debater o uso das categorias Miss Mulata e Miss Morena Cheirosa para designar certas personagens femininas de grande destaque nas quadrilhas juninas de Belém. Mais precisamente, busco problematizar como certas Fundações Culturais, vinculadas às administrações municipais e estaduais de Belém e do Pará, atuam delineando os contornos da "tradição" no contexto performático da "cultura popular", produzindo sujeitos generificados, racializados e sexualizados no âmbito dos concursos juninos.

Ao interpelar o manejo das categorias Miss Mulata e Miss Morena Cheirosa por parte de Fundações Culturais que representam o poder do Estado nos concursos de quadrilha de Belém, pretendo discutir o aparato discursivo mobilizado por gestores culturais, enfatizando seus pontos de vista no que tange à delimitação de certas categorias classificatórias presentes nesses certames. ${ }^{1}$ Embora o foco principal de análise incida sobre os agentes do Estado, pretendo mostrar como esse mesmo Estado não é unívoco, pois é constituído por um conjunto de forças políticas, conflitantes e complementares entre si, tal como propõe Abrams (1988).

De um lado, os quadrilheiros reinventam continuamente a "tradição" e pressionam as Fundações Culturais a admitir essas inovações no contexto dos certames juninos. Do outro lado, o ímpeto realizador dos gestores cul- 
turais do Estado captura essas inovações e as transforma, dentro de certos limites, em regras presentes, de modo explícito ou implícito, nos regulamentos que orientam os concursos juninos. Neste caso, busco analisar o uso das categorias Miss Mulata e Miss Morena Cheirosa nas políticas dos gestores culturais do Estado, nos regulamentos produzidos para os certames e/ou nos discursos que se constroem em torno dos regulamentos. Assim, entendo que a construção do Estado se dá em processo, cotidianamente e performaticamente através de discursos, práticas e regulamentações com amparo legal (Souza Lima 2012).

Para empreender esse debate, montei um argumento baseado na seguinte estrutura sequencial: 1. apresento o contexto de realização do trabalho de campo; descrevo resumidamente a atuação política das Fundações Culturais que promovem as festas juninas e explico a dinâmica de realização dos concursos de quadrilha e de miss, atentando para as implicações do processo de acessar os regulamentos dos certames; 2 . debato algumas representações (pautadas na interseção de gênero, raça e sexualidade) que produzem uma imagem magnificada de Belém e que estarão diretamente implicadas na concepção que os gestores culturais têm acerca da categoria Morena Cheirosa; 3. problematizo os discursos dos gestores culturais do estado acerca das categorias Mulata e Morena Cheirosa nos concursos juninos; 4. Aponto que, apesar de os regulamentos dos concursos apresentarem certos silenciamentos relativos à questão racial, este fator não indica ausência de prescrições normativas quanto às categorias de miss, pelo contrário, indica que essas prescrições normativas existem, mas estão implícitas nos discursos e nas práticas dos gestores culturais.

Ao final do artigo pretendo evidenciar que, ao optarem por adotar a categoria Miss Morena Cheirosa em detrimento de Miss Mulata (anteriormente utilizada), os gestores culturais buscam circunscrever essa personagem feminina para que ela corresponda, performaticamente em termos de gênero, raça e sexualidade, às representações construídas em torno de uma imagem magnificada da própria cidade de Belém. Utilizando a imprecisão de uma categoria êmica, a morena, esses gestores culturais estão implicitamente fazendo referência a uma categoria racial ética, a cabocla, consagrada na bibliografia antropológica que discute as relações raciais na Amazônia. Nestes termos, proponho que a ambiguidade semântica da categoria cabocla é a equivalente amazônica para a indefinição semântica da categoria morena. Buscarei demonstrar que o advento da Morena Cheirosa permite (aos olhos dos gestores culturais) que esta categoria classificatória seja a corporificação feminina de Belém, estabelecendo, por meio da performance dançada, uma relação metonímica com a cidade, sendo uma significante da outra. 


\section{Trabalho de campo, Fundações Culturais, concursos juninos e regulamentos}

A análise aqui presente é fruto de intenso trabalho de campo realizado entre 2012 e 2016 com vistas a produzir uma pesquisa de maior escopo (Noleto 2014, 2016a, 2016b, 2017), cujo intuito foi compreender as lógicas quadrilheiras que orientam a produção dos concursos juninos de quadrilha e de miss em Belém. A pesquisa desenvolvida perscrutou as conexões existentes entre os campos de investigação da cultura popular, das relações étnico-raciais e, por fim, dos estudos de gênero e sexualidade numa perspectiva contemporânea em que gênero, raça, etnicidade e sexualidade são entendidos como marcadores sociais da diferença articulados, de modo interseccional, entre si. ${ }^{2} \mathrm{O}$ trabalho de campo consistiu em acompanhar os concursos juninos realizados pela Prefeitura de Belém através de sua Fundação Cultural do Município de Belém (Fumbel), e pelo governo do estado do Pará por meio da Fundação Cultural do Estado do Pará (FCP/Centur). ${ }^{3}$

Além de pesquisar esses concursos reconhecidos pelos quadrilheiros como "oficiais", acompanhei os certames realizados nos bairros "periféricos" da cidade, organizados por produtores culturais e lideranças comunitárias de bairros como Jurunas e Benguí, situados na região metropolitana de Belém. ${ }^{4}$ Entretanto, a discussão do presente texto está concentrada apenas nos regulamentos dos concursos juninos e nos discursos construídos em torno deles pelos gestores culturais. Sendo mais específico, este artigo problematiza como esses concursos produzem noções normativas de raça e etnicidade através da produção das categorias Miss Mulata e Miss Morena Cheirosa, articulando-as a concepções específicas de gênero e sexualidade.

Para uma melhor apreensão do contexto, é necessário entender como a FCP/Centur (estado) e a Fumbel (município) se situam no seio de políticas públicas voltadas para a cultura. Ambas atuaram ao longo dos anos a partir de orientações políticas sensivelmente (mas não completamente) distintas. Os governos locais (mas sobretudo o estadual) se esforçaram para restaurar o patrimônio histórico e arquitetônico de Belém, reinventando e concedendo-lhe um lugar na história. Ocuparam-se em construir "pontos turísticos" para os visitantes "estrangeiros", reavivaram a cultura "erudita" (produzida pelas elites na Era da Borracha) através da realização anual de pomposos festivais de ópera, estimularam o mercado fonográfico local a partir das leis de incentivo à cultura. Houve ainda um movimento mais expressivo (sobretudo relacionado aos governos municipais) de valorização 
daquilo que se entende como "cultura popular", promovendo o incentivo aos blocos carnavalescos de rua, às escolas de samba, aos grupos parafolclóricos, às festas juninas, aos grupos de carimbó, aos Bois-bumbás e aos Cordões de Pássaro e de Bicho. ${ }^{5}$

De alguma forma, esses investimentos polarizaram no imaginário local uma dicotomia situada entre os governos estaduais "elitistas" - que deram maior destaque à cultura "erudita" do Pará e construíram pontos turísticos vistos como inacessíveis aos pobres - e os governos municipais "populares" - que supostamente mantiveram a preeminência de uma cultura popular produzida pelas/nas "periferias" da cidade. Na transição entre os séculos XX e XXI, essa dicotomia estava expressa também em um sentido estritamente político, pois, de um lado, assistia-se à administração estadual sendo realizada pelo PSDB, na figura do então governador Almir Gabriel e, de outro lado, havia a administração municipal sendo desempenhada pelo PT, na figura do então prefeito Edmilson Rodrigues. A própria origem partidária dos representantes do Poder Executivo da época reforçava o sentimento de oposição entre investimentos "elitistas" e "populares" no que diz respeito à produção cultural da e na cidade de Belém.

É nesse contexto de polarização política e de orientações diferenciadas para as políticas públicas em cultura que atuam a FCP/Centur (estado) e a Fumbel (município). Por este motivo, vencer um certame junino organizado pela Fumbel é conquistar o título mais respeitável para uma quadrilha ou miss no São João de Belém, tendo em vista que esta fundação é percebida pelos quadrilheiros como mais próxima das políticas culturais voltadas para os grupos de cultura popular. Quando em 2014 perguntei a Suellen Silva (Miss Mulata da quadrilha Sedução Ranchista) o significado de ser tricampeã pela Fumbel, obtive a resposta de que "ganhar a Fumbel é o maior sonho de toda miss e de toda quadrilha porque a Fumbel tem tradição no São João de Belém". Isto significa dizer que os quadrilheiros reconhecem a importância da histórica relação entre essa fundação cultural e os grupos de cultura popular da cidade.

Comparados aos certames do governo do Pará, os concursos realizados pela prefeitura possuem uma história mais longeva e um diálogo mais próximo com as populações que residem nos bairros "periféricos" de Belém. Assim, os quadrilheiros consideram o concurso da Fumbel como o mais importante evento oficial da quadra junina de Belém. Em contraponto aos concursos estaduais, que acontecem há cerca de 15 anos de forma contínua e sistemática, os concursos municipais têm cerca de 34 anos de realização. Não quero com isso dizer que não houve iniciativas anteriores por parte da FCP/Centur. Pretendo afirmar que a inserção oficial desses certames como 
parte importante da programação cultural promovida pelo governo só se deu a partir de 2003. E, na concepção dos quadrilheiros de Belém, o concurso da Fumbel tem maior "tradição" e maior campo de diálogo com a dinâmica de produção junina.

Entretanto, os investimentos em cultura por parte das duas Fundações não podem ser classificados dicotomicamente como "elitistas" e "populares", pois ambas, cada uma à sua maneira, realizaram políticas culturais que beneficiaram manifestações artísticas situadas tanto no campo de produção da cultura reconhecida como "erudita" quanto daquela classificada como "popular". A diferença entre as Fundações culturais não reside de modo dicotômico em suas ações, mas nas ênfases dadas a determinados segmentos artísticos - o que traduz suas respectivas orientações políticas. Embora seja impossível classificar os investimentos em cultura de forma tão dicotômica, é relevante observar que todos eles, em conjunto, operaram no sentido de aquecer um mercado da cultura como produto em Belém e em algumas regiões do Pará.

Apesar de este texto não estar pautado numa abordagem etnográfica dos concursos juninos em questão, é necessário entendê-los ainda que resumidamente. Os certames (realizados pela Fumbel, FCP/Centur ou por produtores culturais das "periferias" da cidade) funcionam basicamente da seguinte forma: cada quadrilha junina faz uma apresentação com cerca de 20 minutos de duração. Porém, antes de cada uma dessas apresentações coreográficas coletivas das quadrilhas, há um certame paralelo, indissociável do concurso de quadrilhas: o concurso de miss. Após o posicionamento da quadrilha na quadra de apresentações, cada uma das misses executa uma coreografia solo com duração de dois minutos. As misses são divididas em três categorias, que só podem ser ocupadas por mulheres cisgênero, ${ }^{6}$ a saber: Miss Caipira, Miss Mulata/Morena Cheirosa e Miss Simpatia. Estas três categorias de miss dançam junto com suas respectivas quadrilhas e, por sua vez, representam diferentes tipos de feminilidades no interior do grupo coreográfico. Somente após a apresentação solo de cada categoria de miss, segue-se a apresentação de sua respectiva quadrilha junina.

Mas há uma quarta categoria de miss cuja performance é possível verificar em outro certame específico e exclusivo. Refiro-me à categoria de Miss Gay ou Miss Mix, destinada a homens homossexuais, travestis, transexuais e pessoas que reivindicam outras identidades transgênero. As Misses Gays/ Mix não dançam, como as outras misses, com suas respectivas quadrilhas, pelo contrário, apresentam suas performances (também com dois minutos de duração) em outro concurso que simultaneamente as destaca e as segrega dentro da quadra junina de Belém. ${ }^{7}$ Para os quadrilheiros, estas categorias de 
miss produzem um grande divisor de gênero que orienta suas compreensões. Em seus próprios termos, os quadrilheiros costumam dizer que os certames de miss dividem-se em concursos de Miss Mulher e concursos de Miss Gay/Mix.

Entendido o contexto, devo lembrar que o presente artigo aborda apenas os regulamentos juninos que fazem referência às categorias de Miss Mulher, excluindo da análise a categoria de Miss Gay/Mix. ${ }^{8}$ A análise enfatiza os usos diferenciados das categorias Miss Mulata e Miss Morena Cheirosa por parte dos gestores culturais que pensam nas políticas públicas voltadas à difusão dos grupos de cultura popular em Belém. Por isso, darei destaque aos discursos veiculados pela Fumbel, tendo em vista que esta fundação tem grande protagonismo na proposição da nova categoria, Miss Morena Cheirosa, como substituta ideal à categoria Miss Mulata. Eventualmente, como contraponto de análise, trarei à baila as categorias Miss Caipira e Miss Simpatia, evidenciando como aparecem nos regulamentos e nos discursos de meus interlocutores.

Para quem não é quadrilheiro, conseguir um regulamento de concurso junino ou qualquer outro documento relacionado à produção desses certames é um desafio. Enfrentei diversos obstáculos para ter acesso a esse material, pois há uma desconfiança, manifestada por parte dos quadrilheiros e produtores culturais vinculados à quadra junina de Belém, quanto às intenções de todo e qualquer sujeito que pretenda acessar os documentos e arquivos que regulam os concursos juninos. Essa dificuldade de tornar públicas as informações reguladoras dos certames ocorre tanto com os concursos realizados nas "periferias" de Belém quanto com os concursos promovidos pela Fumbel e pela FCP/Centur. Em geral, os regulamentos são oficialmente divulgados pelos organizadores dos certames de modo impresso, afixados em cartazes e quadros de aviso das instituições públicas que os promovem e são diretamente entregues aos dirigentes de quadrilhas através de reuniões convocadas para a época que antecede a quadra junina.

Apenas em período recente, desde 2012, tem havido uma maior preocupação em tornar públicas as regras que regem os certames, de modo a compartilhar tais regulamentos em veículos de informação com amplo acesso. No caso das Fundações municipais e estaduais que promovem ações culturais em Belém e no Pará, os regulamentos são, algumas vezes, disponibilizados em suas respectivas páginas na internet. Entretanto, ainda assim não se trata de uma divulgação sistemática e clara, pensada para facilitar o acesso a um público mais amplo que deseje acompanhar de perto as ações do Estado no campo cultural. Isto quer dizer que os regulamentos, com muita frequência, ficam dispostos em links difíceis de achar no interior de seus respectivos sites institucionais. 
Entretanto, a situação mais difícil a ser enfrentada é o fato de que tanto no âmbito da Fumbel quanto no âmbito da FCP/Centur não há uma política eficiente de arquivamento on-line e off-line desse material para consultas posteriores. Isto ocorre por conta das sucessivas mudanças de administração municipal e estadual que, ao assumirem seus cargos temporários, estritamente vinculados a um período político específico, promovem mudanças nos sites institucionais e na forma de promover ações voltadas à cultura popular e/ou erudita em Belém e no Pará. Como resultado disto, ainda que as mudanças de administração no Poder Executivo ocorram no interior de um mesmo partido político, há uma espécie de apagamento do legado de ações culturais deixado por administrações anteriores e, assim, perdem-se arquivos importantes quanto ao registro de informações pertinentes ao setor cultural. Algumas vezes é possível encontrar nos Diários Oficiais do Município de Belém e do Estado do Pará algumas diretrizes gerais que regem apenas a destinação de verbas aos certames juninos, divulgando os montantes em dinheiro a serem investidos nas programações culturais. Porém, as regras detalhadas, relativas aos itens de julgamento nos certames, às interdições destinadas às performances das quadrilhas, às recomendações quanto à desenvoltura dos quadrilheiros em cena e às regulações dos concursos de miss, não ficam disponíveis nesses arquivos dos Diários Oficiais, cabendo a cada fundação cultural a emissão e a divulgação de seus documentos específicos de caráter normativo.

No que diz respeito aos concursos das "periferias", organizados por produtores culturais associados aos seus bairros de origem, os regulamentos dos certames acabam circulando de modo informal através de cópias de seus respectivos conteúdos veiculadas nas redes sociais (como o Facebook) ou nos aplicativos de comunicação instantânea (como o Whatsapp). Em todo o caso, é necessário estar atento às redes de relações por onde esses documentos circulam para que se possa ter acesso a eles. Recentemente, a partir de 2015, o Grêmio Recreativo Jurunense Rancho Não Posso me Amofiná, agremiação carnavalesca à qual a quadrilha junina Sedução Ranchista está vinculada, tem divulgado pela internet, de maneira sistemática e suficientemente acessível a toda e qualquer pessoa interessada, os regulamentos dos certames juninos que promove, incluindo nesse rol os concursos de sujo (ou concursos de ensaio), os concursos de quadrilha (durante a quadra junina), os concursos de Rainha do São João (voltados para mulheres cisgênero) e os concursos de Miss Caipira Gay/Mix (indicados para homossexuais e pessoas "trans"). A divulgação promovida pelo Rancho ocorre tanto no Facebook quanto em seu site oficial. ${ }^{9}$

Após ter conseguido, paulatinamente, conquistar a confiança de certos quadrilheiros dessas "periferias" de Belém e de alguns dos principais fun- 
cionários das instituições culturais do estado, explicando o conteúdo de meu trabalho e demonstrando seriedade em minha pesquisa, consegui ter acesso aos regulamentos que me interessavam. Isto não significa que tal acesso se tornou fácil a partir do estabelecimento de vínculos mais fortes com meus interlocutores, mas sim que passei a ser percebido com menos desconfiança, embora esse sentimento fosse sempre manifestado quando o assunto eram os regulamentos juninos.

Ressalto que manifestei meu interesse em participar das reuniões que discutem anualmente a elaboração dos regulamentos dos certames por parte da FCP/Centur e Fumbel. Contudo, não fui informado previamente da convocação dessas reuniões por parte de nenhum dos muitos gestores culturais com os quais tive contato ao longo do trabalho de campo. Soube da realização das reuniões somente após já terem ocorrido. Por um lado, percebi que os gestores culturais do estado não estavam interessados em desnudar certas práticas autoritárias na imposição das regras que orientam os concursos juninos. Por outro lado, entendi que os quadrilheiros, diante de uma relação de poder assimétrica com o estado, não tinham certeza se poderiam me convidar a participar das reuniões ou se esse possível convite seria visto negativamente por parte dos gestores culturais. Ainda que não tenha participado das reuniões (o que me impediu de elaborar uma etnografia do processo de produção dos regulamentos), identifiquei que, na verdade, os regulamentos não eram exatamente produzidos em conjunto pelas Fundações e pelos quadrilheiros, de uma maneira processual em sentido estrito. As Fundações elaboravam os regulamentos e convocavam reuniões para apresentar um documento pronto, esperando reações e objeções dos quadrilheiros, mas nem sempre atendendo às demandas colocadas por eles. Entretanto, ainda que tenha enfrentado dificuldades, tive acesso a todos os regulamentos de que necessitei e, por isso, dediquei-me à análise dos documentos que tinha em mãos.

Mas esta característica de certa inacessibilidade aos regulamentos não afetava apenas a mim como pesquisador, mas aos próprios quadrilheiros que se constituíam como brincantes em seus grupos. Percebi que eram poucos os quadrilheiros que tinham acesso ao processo de produção dos regulamentos, aos regulamentos em si e às discussões que eles suscitavam. Em geral, o conhecimento acerca de tais documentos era centralizado nas figuras dos dirigentes das quadrilhas. Mesmo os coreógrafos, os estilistas e as misses, sujeitos com os quais convivi durante a maior parte do tempo de minha observação participante, não detinham os regulamentos em suas mãos e, consequentemente, não possuíam um conhecimento abrangente acerca de todas as regulações que interferem na realização dos certames. E isto explica, 
em parte, minha própria dificuldade de acessar esses documentos. Com o foco de análise direcionado para o protagonismo da diversidade sexual e de gênero presente nas festas juninas de Belém, estabeleci relações de confiança com os sujeitos que integram o cerne homossexual e "trans" da quadra junina, em geral coreógrafos, dançarinos, estilistas e misses gays. No entanto, minha inserção entre dirigentes de quadrilha, âmbito mais heterossexual e cisgênero, foi realizada de modo indireto, por meio das redes de relações que constituí com a ala criativa da quadra junina. Ainda sim, consegui estabelecer vínculos importantes que me possibilitaram ter acesso aos documentos que pretendia analisar.

A análise desses documentos é relevante para expor as lógicas quadrilheiras produzidas a partir do diálogo (assimétrico) entre os sujeitos das "periferias" de Belém e os agentes do estado, funcionários que pensam nas políticas culturais desenvolvidas pelos poderes públicos locais. Particularmente, afino-me com a análise de que "diversos agentes em diferentes instâncias atuam na regulação dos conteúdos simbólicos da tradição" (Menezes Neto 2008:50), que parte da ideia de que "o regulamento torna-se uma ferramenta de controle dos conteúdos legitimada pelos próprios quadrilheiros. O documento já é por si uma forma de registrar e oficializar o que deve conter uma apresentação e o que não deve, sob ameaça de penalidades" (Menezes Neto 2008:60).

Assim, é preciso considerar que há uma assimetria de forças nesse campo de disputas entre quadrilheiros, agentes do estado e produtores culturais que fomentam os certames nas "periferias". A relação entre os quadrilheiros e esses produtores culturais é mais fluida, com diálogo mais imediato e, de certa forma, os quadrilheiros têm maior campo de agência. No que se refere à relação entre os quadrilheiros e o estado, a assimetria de forças é mais profunda, pois as negociações se dão entre sujeitos sociais específicos e uma entidade político-administrativa abstrata muito pulverizada, burocratizada e poderosa. Os regulamentos dos certames e seus critérios de julgamento têm, portanto, muita influência na produção criativa e performática dos quadrilheiros. Por um lado, o estado (e)dita regras que influenciarão na confecção dos próximos regulamentos dos concursos das "periferias". Por outro lado, os quadrilheiros trazem de suas "periferias" demandas que transformam, a partir de tensas negociações, as diretrizes propostas pelo estado no que tange à regulamentação dos certames futuros. Sendo assim, consultei regulamentos de certames, fichas de inscrição, mapas de apresentações de quadrilhas e misses, manuais de jurados e materiais de divulgação dos concursos juninos para entender melhor como esses certames juninos constroem uma lógica específica de performance artística. Esses 
documentos consultados são relativos tanto aos concursos promovidos pela Fumbel (município) e FCP/Centur (estado) quanto aos certames organizados nas "periferias" da cidade.

Pretendo frisar ainda que meu foco de análise incide, sobretudo, em questões de gênero, geração, raça e sexualidade articuladas como marcadores sociais da diferença. Muitos trabalhos anteriores, como os de Luciana Chianca (2006, 2013a, 2013b), Hugo Menezes Neto (2008, 2015) e Zulmira Nóbrega (2010, 2012), dedicaram atenção aos processos estruturais que fazem acontecer os certames juninos e às negociações entre "tradição" e "modernidade". Menezes Neto $(2008,2015)$, por exemplo, analisou detalhadamente como esses processos de disputa entre "tradição" e "modernidade" se dão na elaboração de regulamentos para os concursos juninos em Recife (PE). Do ponto de vista da dança, Eleonora Leal $(2004,2011)$ documentou e interpretou os processos de mudanças coreográficas verificadas ao longo dos anos de realização de certames juninos em Belém. Tais modificações foram indiretamente impelindo a transformação dos regulamentos juninos. Embora Leal não construa um argumento neste sentido, o trabalho empreendido pela autora demonstra como os quadrilheiros, a partir de suas inovações artísticas, acabam por forçar mudanças na forma de avaliar os certames.

Por considerar que todos estes autores deram grandes contribuições para o debate sobre as negociações entre "tradição" e "modernidade", minha análise dos regulamentos juninos caminha em sentido diverso. Meu foco está nas questões de gênero, raça e sexualidade evocadas nos regulamentos. Como irei argumentar, nem sempre estas questões aparecem de modo explícito, com regras claramente escritas, mas, pelo contrário, muitas vezes as questões normativas que dizem respeito a certos marcadores sociais da diferença aparecem de modo implícito. Neste sentido, minha pergunta norteadora consiste em saber de que modo os regulamentos dos certames juninos produzem gênero, raça e sexualidade. Mais do que olhar para o que dizem os regulamentos, pretendo perscrutar o que eles não dizem, atentando para o conhecimento prático dos quadrilheiros quanto ao caráter normativo dos certames, para as práticas e os discursos dos gestores culturais que idealizam esses concursos juninos e, finalmente, para as concepções nativas que esses sujeitos (os quadrilheiros e os gestores) mantêm especialmente acerca de gênero, raça e sexualidade.

Em depoimento concedido a mim em fevereiro de 2013, Maria de Fátima Pinheiro (Fafá Pinheiro) - coordenadora da Gerência de Linguagem Corporal (GLIC $)^{10}$ da FCP/Centur e principal organizadora dos concursos juninos em âmbito estadual - afirmou que a programação composta pelos concursos de quadrilha e de miss (tanto para mulheres cisgênero quanto para homosse- 
xuais e pessoas "trans") foi inserida oficialmente no calendário cultural da FCP/Centur no ano de 2003, embora a fundação cultural exista desde 1986. Por outro lado, no que tange aos concursos realizados em âmbito municipal, as pesquisas de Eleonora Leal (2011:56) registram o seu surgimento na cena cultural de Belém no ano de 1984, quando a Prefeitura Municipal de Belém instituiu um concurso oficial organizado pela Secretaria Municipal de Educação (Semec).

Documentando transformações coreográficas que marcaram a passagem de grupos juninos denominados "Quadrilhas Roceiras" (1960-1970) para "Quadrilhas Modernas" (1980) e, posteriormente, sua transformação em "Quadrilhas Roceiras Modernas" (1990-2000), Leal (2004) afirma que, desde os primeiros concursos municipais, "o regulamento do concurso da Semec concentrava as suas normas na conservação da coreografia tradicional, deixando os coreógrafos mais temerosos em ousar, ao criarem outras combinações na coreografia da Quadrilha Roceira" (Leal 2004:86). Assim, a autora registra que houve certos embates entre os quadrilheiros e o poder público, pois os coreógrafos "começaram a interferir moderadamente na estrutura da forma coreográfica da quadrilha, ocasionando assim algumas alterações no regulamento do concurso pela insistência de uma categoria (os quadrilheiros) em querer manifestar suas inspirações artísticas" (Leal 2004:86).

Em 2016, quando Belém sediou o XVI Concurso Nacional de Quadrilhas Juninas, houve um exemplo muito significativo de como os quadrilheiros pressionam o estado a respeitar as especificidades dos concursos juninos do Pará. Visando adaptar as quadrilhas paraenses ao formato adotado no certame nacional, a Fumbel exigiu que, mesmo no concurso municipal que ocorre anualmente, os quadrilheiros montassem seus grupos de acordo com outros padrões: usando cenários (as quadrilhas de Belém não os utilizam); inserindo uma dramaturgia baseada numa história de casamento (em Belém, a ênfase está na coreografia dançada e o matrimônio é raramente realizado); apresentando casais de noivos (as quadrilhas paraenses não possuem noivos); e, finalmente, adotando marcadores que interagem com a quadrilha, público e jurados por meio da fala em microfone (os marcadores de Belém comandam a coreografia através de gestos). ${ }^{11}$ Ou seja, se quisessem concorrer ao certame municipal da Fumbel em junho de 2016, todas as quadrilhas deveriam se apresentar adotando o formato do concurso nacional, que só ocorreria em agosto do mesmo ano.

Diante disso, houve uma forte reação dos quadrilheiros nas redes sociais: perfis como "Papo de Quadrilha" e "Quadrilheiros Paraenses" apoiaram campanhas que diziam "FUMBEL, por favor, não roube nossa cultura". Em textos veiculados nas redes sociais, os quadrilheiros afir- 
mavam se sentirem desrespeitados em suas especificidades culturais, tendo em vista que o novo formato imposto divergia dos padrões adotados pelas quadrilhas de Belém. Ainda que a campanha tivesse ganhado certa repercussão com a hashtag \#somosquadrilheirosparaenses, a Fumbel manteve a imposição. Por outro lado, a FCP/Centur não impôs essas mesmas regras. Sendo assim, as quadrilhas que não adotassem o formato imposto pela Fumbel não seriam desclassificadas no concurso da FCP/Centur. Este episódio revela que, embora as pressões exercidas pelos quadrilheiros não sejam acatadas de imediato, elas podem suscitar discussões que resultarão na flexibilização dos regulamentos nos próximos anos. Assim, mesmo que numa assimetria de forças, os quadrilheiros contribuem ativamente com a construção das políticas culturais, ajudando, de certa forma, a moldar a face do estado. Sobre este aspecto, o estilista junino e carnavalesco Jean Negrão certa vez me relatou que "muitas vezes, a Fumbel age de forma autoritária, querendo definir a cultura de cima pra baixo, mas depois ela acaba tendo que reconhecer que quem faz a cultura são os quadrilheiros. E aí as regras do São João vão mudando".

\section{Metáforas sensoriais: cheiros e sabores de Belém}

Antes de analisar os regulamentos juninos e os discursos construídos em torno deles acerca dos usos das categorias Miss Mulata e Morena Cheirosa, é necessário entender que a disputa pela vigência de uma destas categorias classificatórias parece estar relacionada às representações que se fazem sobre Belém num imaginário local. Para compreender este argumento, é preciso apresentar primeiramente essas representações de Belém. Pretendo trabalhar com os estereótipos que se constroem a seu respeito nos discursos veiculados pelo senso comum, pela mídia, pelo cancioneiro popular. Essas representações estereotipadas da cidade serão muito úteis para compreender posteriormente as conexões existentes entre uma imagem magnificada de Belém e o advento da categoria Morena Cheirosa nos concursos juninos. Passemos, adiante, às representações.

Há um consenso muito disseminado de representações possíveis a respeito de Belém, que constitui a cidade em termos de figuras de linguagem que a personificam. Neste senso comum, Belém emerge como "cidade morena", "morena cheirosa" e "cidade das mangueiras". Para nós, os antropólogos, esses estranhos sujeitos que veem potencialidades de discussão em uma simples definição carinhosa de cidade, tais representações podem dizer muita coisa. Há ainda outras representações, construídas nos 
discursos sobre Belém, aparecendo sob o formato de frases soltas que dizem coisas sobre os "cheiros do Pará" (sempre mencionados no plural) e que desenham Belém como a terra do Círio de Nazaré (uma das maiores procissões católicas do mundo). ${ }^{12}$ Essas compreensões arraigadas e que, de certa maneira, visam positivar uma imagem de cidade, falam da chuva infalível que banha as ruas de Belém em todas as tardes e dos sabores irresistíveis (também sempre pluralizados) do tacacá, do sorvete de cupuaçu, do creme de bacuri, da caldeirada de peixe e do espesso açaí tomado diariamente pelos "verdadeiros" paraenses.

Essas representações sugerem que Belém é uma comunidade imaginada em termos sensoriais. ${ }^{13}$ Não é possível conhecê-la nem saber nada a seu respeito sem antes degustá-la em seus sabores, senti-la em seus cheiros, molhar-se em suas chuvas, viver a cidade como uma experiência dos sentidos. Mais do que isso, é necessário entender que Belém é uma cidade produzida a partir de um feminino racializado que a faz "morena cheirosa", unificando sob uma mesma denominação os sentidos da visão que enxerga a raça e do olfato que capta o aroma. Nesta lógica, Belém é uma cidade-mulher, referida sempre no feminino, que parece personificada em cada rosto "moreno" (ou "caboclo"?) das jovens mulheres que transitam pelas ruas. Há um entendimento generificado de Belém que a torna faceira e misteriosa, fixando-lhe características que só podem ser compreendidas em termos que dizem algo acerca de feminilidades.

Se é possível reconhecer as dimensões de gênero que edificam certo imaginário relativo a Belém por meio do uso de metáforas femininas, estas descrições não se referem apenas a uma dimensão de ternura. Existe uma ideia de ato sexual subjacente às metáforas gustativas que a definem: Belém é para ser comida. Há uma sexualidade "selvagem", porém "benevolente", "ingênua", que parece compor essa identidade feminina de cidade. É interessante notar como o imaginário racial brasileiro vai sendo construído historicamente através de metáforas gustativas que relacionam gênero, raça e sexualidade. A literatura, a música e o cinema têm exemplos abundantes. ${ }^{14}$ Em especial no terreno semântico da feminilidade, a figura da mulher miscigenada é habitualmente vinculada a sabores "incomuns" de temperos, frutas e pratos culinários que devem ser consumidos. No Pará, uma classificação que costuma ser utilizada para designar mulheres racialmente híbridas (nem "indígenas" nem "negras") é a categoria "morena cor de jambo", associando raça e gênero a uma fruta muito apreciada na Amazônia. Essas representações dizem respeito à construção de um imaginário racial em que os predicados da raça e do gênero estão definidos por metáforas gustativas que sexualizam os corpos femininos, associando-os, metonimicamente e 
por sugestão implícita, ao ato sexual, a sabores supostamente tão "exóticos" quanto o próprio resultado da miscigenação racial.

E para discutir a construção dessa imagem magnificada de Belém em termos de gênero, raça e sexualidade, inspiro-me na perspectiva teórica de Anne McClintock. Ao estudar a produção dos nacionalismos, a autora denuncia que

as nações não são simplesmente fantasmagoria das mentes, mas práticas históricas nas quais a diferença social é tanto inventada como representada. [...] Mas se a natureza inventada do nacionalismo ganhou ampla circulação teórica, as explorações do gênero em relação ao imaginário nacional permanecem escassas (2010 [1995]:518).

Entretanto, no decorrer de sua obra monumental, McClintock é convincente ao revelar como a produção dos nacionalismos está enraizada na articulação de concepções arraigadas acerca de gênero, raça e sexualidade. ${ }^{15}$ No caso de minha pesquisa, sugiro que a construção da imagem de Belém, com base em um feminino racializado e sexualizado, corresponde a uma manifestação regional dos efeitos de um processo que ocasionou a construção da identidade nacional brasileira. ${ }^{16}$

Por ser "morena", Belém é uma cidade marcada como terra de não brancos. Por estar "longe" de certos pontos "centrais" do Brasil, Belém pode ser facilmente qualificada como uma porta de entrada para o reino do atavismo que, em um entendimento bastante disseminado, é a Amazônia. Belém é terra de "caboclos", esses seres híbridos, difusos, que não são nem grupo racial específico, nem um aglomerado étnico. No estereótipo, Belém é terra quente demais e úmida demais, por isso, parece inviável. É composta de uma população que acredita demais e, por isso, é arrebatada por uma esmagadora fé católica. Belém é cidade hiperbólica. Essas representações estereotipadas fazem de Belém uma cidade-folclore, uma lenda amazônica ensimesmada, um lugar que, quando se vai até lá, tem-se a sensação de mover-se em grandes distâncias no espaço, mas sobretudo no tempo. ${ }^{17}$

Quero trabalhar com a complexidade dessas representações em suas potencialidades agradáveis e incômodas, oferecendo um retrato mais abstruso de meu contexto etnográfico. Nenhum lugar e nenhum sujeito são plenamente inteligíveis a partir de uma única face que os define. Reconheço também o outro lado da moeda: há um enorme potencial político nessas representações. Afirmar-se "morena" e ratificar a importância de suas chuvas é também uma forma de posicionar-se no mundo a partir do estabelecimento de diferenças, tornando evidentes demandas específicas, ressignificando o pejorativo em valorativo e, finalmente, salientando um senso de comunidade 
que concede inteligibilidade para si. Essas representações serão retomadas adiante para uma compreensão mais profunda da categoria Morena Cheirosa nos concursos de miss.

\section{Raça e etnicidade em perspectiva}

Entendido o contexto dos concursos juninos e as representações raciais e de gênero construídas sobre Belém, quero agora problematizar a presença da "raça" como categoria e objeto de regulação nos certames juninos. "Raça" ganha preeminência nos concursos de miss, nos quais as regulações em torno de classificações raciais figuram de modo implícito, através da disputa de nomenclatura referente à categoria de Miss Mulata ou Morena Cheirosa ou mesmo na determinação dos gêneros musicais que as candidatas devem dançar nos concursos. Para que se entenda de modo bem objetivo a dinâmica na qual o concurso feminino de miss se insere na quadra junina, recorro ao regulamento da FCP/Centur, mais especificamente ao capítulo que dispõe sobre o formato estruturado das apresentações. O regulamento diz:

\section{CAPÍTULO II - DAS APRESENTAÇÕES}

Art. 10 - O XII CONCURSO ESTADUAL DE QUADRILHAS JUNINAS (Categorias Adulto e Mirim) e o CONCURSO DE MISS Caipira, Mulata Cheirosa e Simpatia (Categorias Adulto e Mirim) e Mix Caipira realizar-se-á em FASE ÚNICA.

Parágrafo primeiro - A apresentação das quadrilhas e o desfile das misses categoria adulta obedecerão à seguinte cronometragem: 02' (dois minutos) para armação, 02' (dois minutos) para o desfile das misses e 15' (quinze minutos mínimo) e 20' (vinte minutos - máximo) para cada quadrilha.

Parágrafo segundo - A apresentação das quadrilhas e o desfile das misses categoria Mirim obedecerão à seguinte cronometragem: 02' (dois minutos) para armação, 02' (dois minutos) para o desfile das misses e 15' (quinze minutos mínimo) e 18' (dezoito minutos - máximo) para cada quadrilha.

Parágrafo terceiro - O início do certame dar-se-á, inicialmente, com o desfile das misses, com um intervalo de, no máximo, 01' (um minuto) entre cada uma, seguido da apresentação das Quadrilhas Juninas.

Parágrafo quarto - A Quadrilha Junina que cumprir o tempo estabelecido neste artigo receberá 01 (um) ponto de bonificação (FCP, 2015, grifos meus). ${ }^{18}$

Comparativamente, sobre esta questão, o regulamento da Fumbel estabelece que: 


\section{CAPÍTULO III - DA APRESENTAÇÃO}

Art. $6^{\circ}$ - A candidata, regularmente inscrita, realizará seu desfile antes da apresentação da Quadrilha Junina que representa.

I - Cada candidata fará sua apresentação no tempo máximo de 02 (dois) minutos, obedecida, obrigatoriamente, a seguinte ordem de apresentação: Miss Caipira, Miss Simpatia e Miss Morena Cheirosa, sendo observado um intervalo de até no máximo 1' (um minuto) entre cada apresentação (Fumbel, 2014).

Percebe-se, portanto, que a apresentação de cada uma das categorias de miss precede a performance de suas respectivas quadrilhas em ambos os certames. Contudo, é notável o fato de que, apesar de trabalharem com três categorias distintas de miss, os regulamentos dos concursos destinados às mulheres cisgênero não estabelecem nenhum critério de diferenciação entre as misses Caipira, Simpatia e Mulata/Morena Cheirosa/Mulata Cheirosa. Supostamente, qualquer candidata cisgênero poderia estar inscrita em quaisquer categorias de miss de sua escolha sem atentar para classificações que a posicionariam racialmente. Porém, sabe-se que isso não seria possível porque, ao menos para candidatar-se ao cargo de Miss Mulata ou Morena Cheirosa, a candidata necessitaria ser percebida como "negra", "morena", "cabocla", "indígena" ou alguma outra denominação correlata. Não obstante o silêncio dos regulamentos, entre os quadrilheiros há um conhecimento prático que faz com que as diferenças existentes entre as três categorias femininas de miss lhes sejam muito evidentes. Neste caso, para apreender essas diferenciações, é necessário observá-las em performance. ${ }^{19}$ Contudo, o depoimento de Gabrielle Pimentel, Miss Caipira da Sedução Ranchista em 2014, é elucidativo quanto às diferenciações que os quadrilheiros fazem em relação às misses.

(Gaby) - A Miss Caipira... ela é a mais importante da quadrilha. Então, a Miss Caipira sempre está de acordo com o tema da quadrilha porque é ela, com o tema individual dela, que representa o tema da quadrilha. Se tu fores perceber, a Miss Caipira é a própria quadrilha. E ela tem que ser a melhor dançarina, melhor que as outras misses porque ela é a mais visada, a mais esperada de todas. Tipo: ela é a rainha! Então, as coreografias têm sempre que ser mais difíceis, surpreendentes, pra deixar o povo de boca aberta. Os temas têm que ser sobre a cultura popular, sobre o nordeste, sobre Belém, sobre a vida dos ribeirinhos do Pará, sobre os animais da Amazônia, coisas assim... Aí, depois da Caipira vem a Miss Mulata. Como eu posso te dizer... a Mulata traz o tema dos negros, dos batuques da Amazônia, dos rituais, da escravidão, qualquer coisa que esteja relacionada com a história dos negros. Aí, a Mulata tem aquela coisa mais 
pesada, umas coreografias mais fortes, com movimentos mais brutos... E a Miss Simpatia é aquela coisa menininha. Ela é a frescura da quadrilha. Sabe aquela coisa de frescar? Pois é, a Miss Simpatia tem que ter muito close, muito sorriso, mas sempre com jeitinho de menina danada, que tá começando a namorar e quer se exibir pra todo mundo. A Simpatia tem que ser toda fresca [risos]. Ela sempre dança umas músicas tipo forrozinho, xote... Ela sempre surge com temas de namoro, de menina que quer ir pras festas. Ou às vezes a Simpatia interpreta uma vendedora de frutas do Ver-o-Peso e até pode dançar uma lenda amazônica, mas não pode perder aquele jeito sensual de menininha, entendeu?

Entretanto, ao observar as candidatas em inúmeros concursos de miss (problematizados em outros textos anteriores, ver Noleto 2014, 2016a, 2016b), percebi que a categoria Miss Caipira era, em geral, ocupada por candidatas mais "brancas". Mulheres com tons de pele mais "escuros" ou feições faciais mais "indígenas" concorriam aos títulos de Miss Mulata ou Miss Morena Cheirosa. Por sua vez, a categoria Miss Simpatia é ocupada por candidatas que poderiam ser racialmente classificadas de diversas maneiras, pois se trata de uma espécie de categoria de acesso aos postos mais emblemáticos de Miss Caipira ou Mulata/Morena Cheirosa. Assim, a Miss Simpatia pode ser "branca", "negra" ou quaisquer outros tipos de classificação racial. ${ }^{20}$

O que vale destacar aqui é que nenhum dos regulamentos consultados define as possíveis candidatas nem em termos raciais, nem no que diz respeito às idiossincrasias performáticas de suas respectivas categorias. ${ }^{21}$ Aproveitando o conteúdo do depoimento de Gabrielle Pimentel e somando-o a outras definições que ouvi de meus interlocutores em campo, quero resumir aqui algumas características sobre cada uma dessas misses. Para os quadrilheiros, a Miss Caipira é a dama mais importante da quadrilha, devendo ser a representante oficial do grupo e dançando ritmos juninos acelerados, como o baião e o xaxado. Por sua vez, a Miss Mulata está tradicionalmente associada a gêneros musicais vinculados à influência cultural "negra" e, mais recentemente, quando passou a ser denominada de Morena Cheirosa, foi relacionada a gêneros musicais amazônicos também ligados a musicalidades "negras", como o carimbó, o siriá e o lundu. Os quadrilheiros apontam que as coreografias das Mulatas ou Morenas Cheirosas são mais "pesadas", ressaltando o caráter enérgico de suas performances. Já a Miss Simpatia é caracterizada por certa indefinição, podendo dançar tanto os gêneros musicais associados à Miss Caipira quanto aqueles mais próximos da Miss Mulata ou Morena Cheirosa. Porém, a Miss Simpatia quase sempre dança xote, forró e carimbó, sendo constantemente avaliada como uma brincante menos experiente, que interpreta coreografias mais "leves" e menos 
"complexas" em relação à Miss Caipira e, por outro lado, que não possui a força cênica das Mulatas ou Morenas Cheirosas.

Não obstante, há uma proibição que impede que candidatas vencedoras no concurso do ano anterior disputem o mesmo título no ano subsequente. Para as brincantes que ocupam o cargo de Miss Simpatia, ganhar um título de campeã pode significar uma grande oportunidade de ascensão ao posto de Miss Caipira ou, dependendo de sua classificação racial, Miss Mulata/ Morena Cheirosa, tendo em vista que, no ano seguinte, não poderá disputar o título que já havia ganhado no ano anterior. Igualmente, para a Miss Mulata/ Morena Cheirosa, caso seja vencedora de um certame, há também possibilidades de mudança de categoria tanto para Miss Caipira quanto para Miss Simpatia. Porém, do ponto de vista do prestígio que a Miss Mulata/Morena Cheirosa tem na quadra junina, mudar para Miss Simpatia seria considerado um retrocesso, restando-lhe apenas a opção de candidatar-se a Miss Caipira.

Entretanto, se uma candidata a Miss Caipira ou Simpatia for considerada "branca", ela certamente será impedida de disputar um título como Mulata/Morena Cheirosa. Isto significa dizer que as candidatas consideradas "negras", "morenas" ou até mesmo "indígenas" têm um maior campo de mobilidade entre as carreiras de miss conforme consigam conquistar títulos na quadra junina. O ponto que pretendo destacar refere-se ao fato de os regulamentos não distinguirem as categorias de miss entre si, mas trabalharem com a compreensão de que, para os quadrilheiros, é óbvio que somente candidatas "negras", "morenas" ou com peles mais "escuras" possam disputar os cargos de Miss Mulata/Morena Cheirosa. ${ }^{22}$ Da perspectiva racial, não são estabelecidos critérios para as ocupantes dos outros dois postos de miss.

Certa vez, Ruth Botelho (técnica cultural da Fumbel e uma das principais vozes de comando na organização dos certames juninos) contou-me que estava cogitando eliminar duas categorias de miss dos próximos certames da Fumbel. A intenção da gestora cultural era diminuir o número de candidatas concorrentes e, assim, agilizar as apresentações das quadrilhas, possibilitando que o público e os jurados ficassem menos cansados ao acompanhar a extensa programação junina. Caso essa mudança fosse implantada, os concursos juninos de miss em Belém se assemelhariam aos concursos juninos de Rainha de outros estados brasileiros, nos quais apenas uma candidata é designada ao posto em cada quadrilha. Conversei com Ruth Botelho sobre o assunto:

(Rafael) - Então, no caso, a proposta seria não ter mais a [Miss] Morena Cheirosa e nem a [Miss] Simpatia. Seria só a [Miss] Caipira, é isso?

(Ruth) - Só a Caipira pra 2015 já. Mas isso, a Fumbel vem tentando há anos e eles [quadrilheiros] sempre batem, sempre batem conosco alegando que a 
Fumbel e o Centur ainda são os órgãos que mantêm essa tradição das três categorias. É, mas a Fumbel realmente pensa em extinguir essas outras categorias [de miss].

(Rafael) - Vamos dizer que ano que vem vocês ficariam somente com a categoria [Miss] Caipira. Aí, por exemplo, a menina que sempre disputou [na categoria Miss] Mulata, que tem a pele mais "escura", tem como ela disputar [na categoria Miss] Caipira ou isso não tem nada a ver? Tem algum problema uma pessoa "morena" ser Miss Caipira?

(Ruth) - Não, fica normal. Ela pode vir [disputar o concurso]. Ao contrário, se a Fumbel só ficasse com a categoria Morena Cheirosa, ela [a candidata] teria que ter essa pele mais "escura" e teria que ter todo um critério para que ela pudesse se inscrever. Mas a categoria Caipira pode vir loira... pode vir "morena"... É Caipira. Isso vai ser com eles [os integrantes da quadrilha].

A intenção de Ruth Botelho é fortalecer um argumento técnico de que uma grande quantidade de misses, em diferentes categorias, seria responsável por um atraso na dinâmica de realização dos certames, tornando-os mais lentos e, por isso, cansativos. A gestora cultural procurou destacar o suposto benefício de que, ao reduzir de três para um os tipos de miss, seria considerada apenas a categoria Miss Caipira que, ao contrário da Mulata/ Morena Cheirosa, poderia ser disputada por candidatas com quaisquer classificações raciais. Entretanto, foi ignorado o fato de que nos concursos juninos realizados nas "periferias" de Belém há uma "tradição" de que três categorias de miss estejam disputando títulos diferenciados. É esta "tradição" e a resistência dos quadrilheiros nos embates com as Fundações Culturais que impediram, até o presente momento, a eliminação das três categorias de miss dos certames juninos paraenses. Ou seja, o estado não conseguiu implantar uma nova dinâmica reduzida para a realização dos concursos de miss. Sugiro que estas três categorias de miss - caracterizadas por dançarem gêneros musicais específicos que não apenas marcam qual o tipo coreográfico de miss que está dançando, mas também delimitam os elementos raciais e étnicos que são performatizados por elas - representam diferentes tipos de feminilidades amazônicas no contexto dos certames juninos.

Para continuar o debate, evoco, neste momento, o trabalho de Eleonora Leal (2011) acerca da documentação do surgimento das quadrilhas modernas na década de 1980 em Belém. Segundo a autora, as quadrilhas modernas eram marcadas por, dentre outras características, utilizarem gêneros musicais que fugissem ao escopo junino. Ao demarcar a passagem da "Quadrilha Tradicional Roceira" (comum na década de 1960/1970) para a "Quadrilha Moderna" (que entra em cena na década de 1980), a autora afirma que 
no início dos anos 80, permanecia em voga apresentar as danças populares após a Quadrilha Tradicional Roceira. Esta começava a dar seus primeiros passos para acrescentar sensíveis novidades nesta década. [...] Os grupos de quadrilhas motivados a dançar distintos gêneros de dança começaram a incluir de três a quatro danças populares no repertório de suas apresentações, tais como o Xote, a Dança Afro, o Forró, o Carimbó e a Macumba, por se encontrarem entusiasmados com os novos vocabulários de movimentos que aprendiam, a ponto de deixarem de se dedicar mais à quadrilha (Leal 2011:53).

Sobre a inserção da dança que denominou como "macumba" na quadra junina a partir da década de 1980, Eleonora Leal (2011) assegura que

a dança da Macumba foi estabelecida no repertório de danças dos grupos de quadrilhas pelo Pai Reginaldo Lopes. Este promoveu um conhecido concurso de quadrilha no bairro do Jurunas, pois achou conveniente divulgar a dança de seu culto religioso por meio dos quadrilheiros. Para isso, incluiu no regulamento a presença desta dança. A partir desse momento, todos que participavam do concurso passaram a inserir nas suas quadrilhas a dança da Macumba (Leal 2011:53-54).

Com base em tais descrições, sugiro que as inserções paulatinas desses gêneros coreográficos no interior da dinâmica dos concursos juninos aludem à própria formulação da concepção coreográfica do que seriam as futuras misses. Em seu trabalho, Eleonora Leal faz referência a essas danças como apresentações coletivas de toda a quadrilha. Mas é possível inferir que os outros gêneros musicais acrescentados nas apresentações de quadrilhas foram aos poucos sendo dançados em números de apresentação solo, o que destacaria o protagonismo de algumas brincantes específicas que, no futuro, seriam as três categorias de miss. No decorrer dos processos de mudanças coreográficas ocorridos nas quadrilhas, nos quais a Fumbel desempenhou um importante papel regulador no sentido de pressionar as quadrilhas a retornarem a um estilo mais "roceiro" e menos "moderno", os gêneros musicais como baião, xaxado, xote, forró e ritmos "afro" foram aos poucos se tornando elementos significantes das diversas categorias de miss. E é neste sentido que pretendo discutir como as categorias de miss resguardam elementos que denotam raça e etnicidade, chegando todas elas à configuração atual na qual a Miss Caipira está relacionada ao baião e ao xaxado (e às vezes ao carimbó), a Miss Mulata ou Morena Cheirosa associada aos ritmos "afro" e batuques amazônicos, e a Miss Simpatia vinculada ao xote e ao forró, mas também a ritmos regionais como o carimbó. Quanto à prescrição dos gêneros musicais a serem dançados pelas misses, os regulamentos da Fumbel são explícitos acerca de impedimentos e recomendações: 


\section{CAPÍTULO IV - DOS IMPEDIMENTOS}

Art. $7^{\circ}$ - É expressamente proibido às candidatas participantes do Concurso de MISS CAIPIRA, MISS SIMPATIA e MISS MORENA CHEIROSA, em quaisquer destas categorias, seja nas versões "ADULTA" ou "MIRIM":

[...] IV - Apresentar-se com ritmos musicais e/ou coreografias não condizentes com a época junina, como, por exemplo: lambadas, calipsos, merengues, rumbas, sambas, frevos, axé music, marchas, melodys, brega, tecno-brega, tecno-melody, pontos afro-religiosos (mesmo que estilizados), dentre outros.

Parágrafo único - Para a apresentação de qualquer uma das categorias das misses simpatia e morena cheirosa, são considerados ritmos musicais condizentes com o período junino, por exemplo: Forró, xote, baião, xaxado, maxixe, galope, carimbó, siriá, lundu, toada de boi, retumbão, batuque, chula. As estilizações de arranjos serão permitidas desde que não descaracterizem a respectiva estrutura rítmica musical (Fumbel, 2014, grifos no original).

Apesar de os regulamentos não definirem explicitamente qual o gênero musical adequado para cada categoria de miss, há uma percepção entre os quadrilheiros sobre os ritmos mais apropriados. Devido a um longo processo anual de aprendizagens, em que os coreógrafos têm acesso às justificativas dos jurados em seus formulários de avaliação das misses, é possível inferir quais são os parâmetros performáticos que as Fundações Culturais e os jurados mobilizam para avaliar as candidatas, incluindo-se nesse rol os gêneros musicais dançados por cada uma delas. Essa associação intuitiva de gêneros musicais a cada categoria de miss conduz ao debate da alteração da nomenclatura de Miss Mulata para Miss Morena Cheirosa, realizada pela Fumbel, que teve reverberações na categoria atualmente adotada pela FCP/Centur, referida como Mulata Cheirosa (uma mistura das duas denominações).

Em 2012, a Prefeitura de Belém resolveu abandonar a categoria Miss Mulata e adotar a designação Miss Morena Cheirosa com o intuito de aproximar o qualificador racial "morena" da designação usualmente mobilizada para descrever Belém como cidade "morena" e "cheirosa", referindo-se, respectivamente, ao caráter "mestiço" que configura a formação racial da população da cidade e aos cheiros dos frutos e dos temperos que integram os ingredientes da culinária local, tais como a manga (Belém também é considerada como cidade das mangueiras) e o tucupi (caldo aromático extraído da mandioca e utilizado para receitas como tacacá e arroz paraense). De acordo com informações coletadas em entrevistas realizadas com Alice Miranda e Ruth Botelho (principais organizadoras dos concursos promovidos pela pre- 
feitura), a designação Morena Cheirosa sublinha o caráter mais "paraense" e "amazônico" pretendido para esta categoria de miss, afastando-se do caráter mais "negro" e "africano", utilizados em anos anteriores nas coreografias dessas misses e percebidos pela organização dos concursos da prefeitura como não amazônicos.

A alegação para o motivo da mudança empreendida pela Fumbel foi o fato de que, historicamente, as Misses Mulatas sempre preferiram dançar gêneros musicais bastante relacionados às religiões de matriz africana presentes em Belém e no Pará como um todo. Do ponto de vista normativo da Fumbel, a influência dessas religiões e desses gêneros musicais "negros" supostamente não é de todo fidedigna à composição étnica, cultural e racial de Belém. Para os gestores municipais, a figura da Miss Mulata estaria literalmente obscurecendo um caráter mais "amazônico" e, portanto, mais "indígena" das populações de pele mais "escura" que compõem o mosaico étnico-racial do Pará. Conversei sobre este aspecto com Ruth Botelho:

(Rafael) - O que eu observei em relação às misses, principalmente em relação à categoria que antigamente falavam [Miss] Mulata e agora é Morena Cheirosa, que elas usavam muita música afro-religiosa, de "macumba"... E esse ano eu percebi uma diferença. Isto também foi uma coisa que foi conversada nas reuniões?

(Ruth) - Nos outros anos sempre é conversado com eles [quadrilheiros]. Só que, ao contrário das outras gestões, [o gênero musical] não estava discriminado no regulamento na categoria das misses. Ano passado [2013] já estava discriminado o que era permitido, o ritmo musical [que era permitido] para cada categoria [de miss]. Como nós tivemos ainda muitas desclassificações por conta do carimbó - porque até o ano passado a Fumbel entendia que o carimbó tinha que ser somente para a Miss Caipira e não para as outras categorias... Então, o carimbó acabou ficando aberto pra que todas as categorias [de miss] pudessem se apresentar. Mas no regulamento é específico, diz os ritmos e diz que tem que ser regional. Não pode fugir! Porque as misses estavam vindo com [ritmos] afro, tinha misses que dançavam com samba! Este ano, pela primeira vez também, tivemos um músico, um doutor [em Música], que foi o Daniel Araújo, que ficou avaliando na coordenação pra poder apontar se era ou não o ritmo [prescrito no regulamento]. E assim nós tivemos poucas desclassificações.

(Rafael) - Muitas das misses Morena, Mulata antes elas usavam muito tema afro...

(Ruth) - Eu acho que é a identidade. Eles acabaram encaixando na cabeça deles que, por ser negro, tem essa questão do afro. E a Fumbel acabou com isso mesmo! Tanto é que a Alice [Miranda, técnica da Fumbel] foi a que pesquisou 
realmente, exterminou essa questão da categoria Miss Mulata. Ela entendeu, explicou que a nossa pele é [cor de] jambo. Por isso, deveria ser a Morena e não a Mulata. E outros concursos estão seguindo o modelo da Fundação. E aí nós abolimos. São poucas as candidatas que ainda vêm com afro. Porque o afro, realmente, desclassifica a candidata.

(Rafael) - No caso, a [categoria de Miss] Morena [Cheirosa] seria mais paraense? (Ruth) - É. É nossa. É daqui. É regional mesmo, característico nosso, né? Como eu te falei: é a pele mesmo cor de jambo nossa. Então, a gente tenta puxar mesmo, manter o tradicional. E aí a Mulata foi realmente abolida.

Ao argumentar sobre a mudança na nomenclatura, Ruth Botelho intencionou realizar uma distinção racial que remete a uma suposta diferença entre a cor da pele da mulher "negra" (isto é, a "mulata") e a cor da pele da "morena" paraense. Embora não diga de modo explícito, sua escala cromática aparenta estabelecer que a "morena" paraense possui uma pele de coloração mais "clara", aproximando-se de um tom de pele característico das populações indígenas. Alice Miranda, também técnica cultural da Fumbel, foi coordenadora (em 2014) dos concursos de quadrilhas mirins e dos concursos de miss nas modalidades adulta e mirim. Em entrevista concedida a mim em 2014, Alice Miranda, usando as palavras "raça" e "etnia" muitas vezes como sinônimos, comentou que

(Alice) - Desde o ano retrasado nós não temos mais a Miss Mulata. Nós temos a Miss Morena Cheirosa. O diferencial maior está entre a Caipira e a Simpatia em relação à Morena Cheirosa. Porque existe uma grande preocupação das quadrilhas juninas em ligar a questão do nome, [que] agora [é] Morena Cheirosa, com a questão da etnia. Então, um dos motivos [por] que a gente trocou o nome de Mulata pra Morena era justamente pra tentar tirar esse estereótipo que elas [as quadrilhas] estavam criando em torno dessa miss. Porque a Fumbel, o nosso concurso ele é tradicional, ainda é um concurso de quadrilha roceira. Diferente de outros concursos aí fora, que são voltados pra temática, trazendo outros assuntos que não estão ligados à questão junina, a Fumbel ainda procura manter essa tradição. Então, a gente percebe que a questão da Mulata era muito amarrada a essa questão afro-religiosa. É claro que a gente sabe que isso faz parte do nosso povo, obviamente. Mas em se tratando de folclore, dessa questão das misses, era preocupante porque eles [os quadrilheiros] associavam demais à questão da pele. A própria Fumbel fazia essa referência. Então, uma forma que nós encontramos de diferenciar e tirar esse caráter "etnia" foi colocar Morena Cheirosa, até porque, em Belém, o que nós temos são as morenas, né? Mesmo que seja um pouquinho mais escura, é morena. 
Para entender quem é essa "morena cor de jambo" tão idealizada pelas gestoras culturais da Fumbel, é necessário problematizar o que Roberto Motta (2000) denominou de o "paradigma da morenidade", presente nas obras de Gilberto Freyre, Marvin Harris e Carl Degler. Na interpretação de Motta (2000), estes autores convergem no entendimento do caráter elástico da categoria "moreno", sendo uma classificação racial imprecisa, que permite múltiplas negociações e cujo fator de confusão estabelece a essência do paradigma da morenidade. Contudo, o discurso das gestoras da Fumbel esconde outra categoria racial presente no imaginário amazônico: a "cabocla". Porém, tais gestoras não utilizam explicitamente a categoria "cabocla" em nenhum momento de suas formulações. Isto se deve à consciência que essas gestoras culturais têm de que a identidade "cabocla", embora presente nas relações raciais amazônicas, é controversa. Conforme demonstrou Fábio Fonseca de Castro (2013), a identidade "cabocla" foi historicamente denegada e, de modo cíclico, é ressignificada em termos positivos por artistas e intelectuais interessados nas relações raciais em contexto amazônico. Assim, o termo "caboclo" é mais uma categoria ética, presente na bibliografia antropológica local, do que uma categoria êmica mobilizada no cotidiano das relações raciais. Sugiro que a imprecisão semântica do termo "caboclo" - que não indica um grupo étnico-racial específico, mas aponta para uma classificação intersticial entre o "negro" e o "indígena" - é o equivalente amazônico à semântica indefinida da categoria "moreno", situada na mistura incerta entre os matizes "negro" e "branco".

Assim, a alteração dos regulamentos para denominar a antiga Miss Mulata como a atual Miss Morena Cheirosa pretende comunicar que, ao invés de designar uma mulher "negra", esta categoria se refere de forma implícita a uma mulher "cabocla", tipicamente paraense, uma classificação mestiça situada nas fronteiras entre ser "negra", "indígena" e "branca": a morena cor de jambo. ${ }^{23}$ Nestes termos, é necessário dimensionar que

se o caboclo não é uma categoria étnica, no sentido estrito do termo, é no jogo da diferença que ele é constituído, assim como outros sujeitos/objetos antropológicos. Como uma diferença, a identidade cabocla é uma fronteira sempre em movimento - de expansão ou retração -, nunca igual a si mesma, sempre em transformação. Nesse movimento, na busca de "tornar-se outro", é que se abre um espaço de reflexividade: ao dar significados à sua experiência de margens e movimentos, o caboclo pode, enfim, autoconstituir-se como uma fala, ao mesmo tempo heterogênea e autônoma, local e nacional, singular e plural (Rodrigues 2006:128). 
É interessante notar o movimento protagonizado pela Fumbel no sentido de estabelecer (implicitamente) como uma identidade étnico-racial específica exatamente uma figura emblemática que, de acordo com o consenso da bibliografia antropológica, representa uma não identidade ou uma identidade que não é definida em si, mas que aparece por contraste, em relação comparativa a uma determinada alteridade. Assim,

o caboclo, geralmente referido no masculino genérico, é representado como uma personificação concreta encarnada no mundo simbólico-prático. Todavia, ele é também aquele que escapa, se esgueirando entre as identidades. Essa complexa figura da mestiçagem é e não é no jogo relacional e contrastivo das identidades: mostra-se/oculta-se, revela-se e é negado ao mesmo tempo em que se nega ao ser revelado. Poucos se dizem caboclos, mas todos bebem de sua fonte (Silveira, Moutinho \& Souza 2015:36).

Advirto para o fato de que essa mudança significativa empreendida pela Fumbel, no sentido de valorizar uma espécie de versão feminina do "caboclo", acompanha uma tendência relativamente atual de ressignificação de uma identidade social que era, antes, denegada. Historicamente, a identidade "cabocla" sempre foi associada ao estigma, ao atavismo, a uma condição degenerativa de mestiçagem. Décio Guzmán (2006), historiador, localiza com precisão o ponto de partida desse estigma. De acordo com o autor,

em 1755 foi editado em Lisboa o alvará real que incitava os europeus de ambos os sexos, provenientes da metrópole e da colônia, a casarem-se com os nativos americanos. Esse documento afirmava que os casamentos guardavam, sobretudo, a finalidade de "concorrer muito à comunicação com os índios" para que os domínios portugueses da América se povoassem. [...] o item desse alvará que mais nos interessa é aquele que coibia a apelação de "Cabouclos" [sic] aos filhos mestiços desses casamentos, pois, segundo o alvará régio, tratava-se de uma alcunha "injuriosa" e "ofensiva". "Caboclo" torna-se, a partir de então, um interdito vocabular oficial [...] As leis da Coroa portuguesa institucionalizaram, no século XVIII, a "invisibilidade" da emergente sociedade cabocla na documentação escrita oficial produzida pelas autoridades do Estado do Grão Pará e Maranhão e no restante do Brasil colonial. O termo "caboclo" é aqui oficialmente estigmatizado (Guzmán 2006:74-75).

Problematizando a emergência discursiva da figura do "caboclo" como uma identidade historicamente negativada - assumida a contragosto pelas populações amazônicas e, por isso, uma identidade denegada - Fábio Fonseca de Castro (2013) demonstra o ressurgimento positivado do "caboclo" ao destacar que 
o momento seguinte na tipificação dos caboclos amazônicos pela intelligentsia paraense aflui nos anos 1970. Ele idealiza o caboclo sem maiores preocupações a respeito de sua dimensão moral, iconizando-o nos diversos formatos que lhe couberam ao longo da história: a indolência já não é problema, bem como a preguiça. Por outro lado, sem que a contradição tipológica seja um problema, o ladinismo e a desfaçatez cedem lugar à esperteza e à inteligência prática. Por meio de políticas e de micropolíticas culturais e midiáticas, a figura do caboclo, nesse período, é inserida no panorama de uma indústria cultural mediana que, à força de simplificar os impasses, acaba resolvendo problemas que para as gerações anteriores foram gigantescos [...] Pode-se perceber a motivação publicitária de obras artísticas, algumas bastante iconizadas, em torno de uma representação do caboclo, algo que dá impressão de que seus autores estão buscando, quase ao desespero, a confecção de uma identidade humana local a ser constituída com base nesse indivíduo, um tanto utopicamente identificado como caboclo (Castro 2013:449-450).

Sugiro que é neste ponto atual da construção discursiva em torno do "caboclo" que a Fumbel se encontra alinhada ao direcionamento contemporâneo dado para a ressignificação positiva da identidade que era antes um estigma. Em outras palavras, afirmo que a transição de Miss Mulata para Miss Morena Cheirosa é representativa de um movimento cultural maior, vigente em Belém, que busca produzir discursivamente significados positivos associados à identidade "cabocla". Embora não usem o termo "cabocla" de modo explícito, os matizes raciais aos quais as gestoras da Fumbel fazem referência, bem como os gêneros musicais dançados pelas Morenas Cheirosas nos concursos juninos apontam para a identidade "cabocla" das populações amazônicas. Se é possível considerar que Belém seja uma comunidade imaginada em termos sensoriais, personificada como uma mulher "morena", representada pelos aromas das ervas amazônicas e pelos odores gastronômicos que caracterizam a culinária paraense, então, a Miss Morena Cheirosa pretende ser a própria encarnação física de Belém no cerne da quadra junina. Assim, há uma relação metonímica entre a imagem magnificada de Belém e a mulher "cabocla" - nem exatamente "negra", nem propriamente "indígena", muito menos "branca".

Se levada a sério esta ideia de que Belém é uma comunidade imaginada em termos sensoriais, especialmente no que diz respeito às representações que relacionam a cidade aos seus sabores culinários, deve-se considerar que Belém é para ser comida. Neste caso, como vimos, a comida exprime igualmente uma metáfora de consumação sexual. Dito isso, pode-se inferir que também reside na categoria de Miss Morena Cheirosa o componente 
sexual que está subjacente ao imaginário construído acerca de Belém. Embora pretendam ser concebidas como diferentes uma da outra, as identidades da Morena Cheirosa - essa mulher reivindicada como "cabocla" - e da Mulata têm afinidades que interseccionam raça, gênero e sexualidade. Mariza Corrêa nos possibilita entender que

no universo textual, ambos, o mulato e a mulata, saíram do âmbito das classificações de sexo para o das classificações de gênero, mas seguindo caminhos diferentes: um transformou-se em agente social, elemento importante para a definição ou constituição da sociedade nacional, outra transformou-se em objeto social, símbolo de uma sociedade (que se quer) mestiça. [...] Raça (seja lá como for que ela tem sido definida ao longo desse debate) é um dos marcadores sociais mais importantes em nossa sociedade, ela, necessariamente, estará presente no campo semântico das definições de gênero (Corrêa 1996:48-49).

Ícones privilegiados da mestiçagem, a "cabocla" e a "mulata" são as personagens centrais, percebidas por seus supostos predicados sexuais essencializados, no processo de reprodução de uma sociedade miscigenada. Ao acompanhar o decurso no qual a identidade "cabocla" é negada e reafirmada situacionalmente, a Morena Cheirosa encontra pontos de convergência em sua relação com a Mulata, tendo em vista que há um corpo discursivo que simultaneamente enaltece e condena a "mulata". Ela é, ao mesmo tempo, desejável e indesejada, uma espécie de mal necessário. ${ }^{24} \mathrm{O}$ fato é que tanto a categoria Miss Mulata quanto a Miss Morena Cheirosa contêm pressupostos racistas que precisam ser problematizados. Por um lado, a figura da "mulata" traz consigo estigmas históricos que sexualizam excessivamente a mulher por via da raça, pois "seu valor é o de exprimir sinteticamente a brasilidade - nacionalidade - através de uma sexualidade exacerbada, posto que não controlada pelos laços de parentesco no interior da família. Assim, suscita/favorece/estimula a comunicação/aliança com o Outro, o estrangeiro" (Giacomini 1994:221). ${ }^{25}$ Por outro lado, o qualificador "morena cheirosa" faz surgir a ideia de que há "morenas" que não são cheirosas e, portanto, cria uma associação problemática entre raça, odores e fluidos corporais de modo a produzir avaliações racistas relativas às noções de impureza e sujeira.

Além disso, a tentativa de afastar dos concursos juninos o caráter "negro" e "africano" da categoria Miss Mulata, ressaltando o aspecto "amazônico", "caboclo" e "indígena" pretendido para a categoria Miss Morena Cheirosa, ecoa um longínquo e equivocado senso comum ainda vigente de que "na Amazônia, contudo, a contribuição cultural do negro é sistematicamente diminuída, e até negada, no conjunto de seus valores constitutivos. O 
negro, menos ainda que o branco europeu, vale dizer o lusitano, quase nada teria deixado de sua presença na região" (Salles 2005 [1971]:93). Portanto, enfatizo que as motivações simbólicas que acarretaram essa alteração na nomenclatura de Miss Mulata para Miss Morena Cheirosa não estão evidenciadas nos regulamentos. As explicações para a adoção dessas mudanças não são passíveis de serem encontradas em nenhum documento oficial, mas consistem em um entendimento que somente é absorvido etnograficamente através da imersão no trabalho de campo, observando as performances das candidatas e, principalmente, ouvindo a voz normativa dos poderes públicos que se constitui como um importante elemento regulador dos significados da cultura popular no contexto paraense.

É necessário, portanto, interpelar os silêncios contidos nos regulamentos, atentando para o que eles não dizem. É interessante notar como em suas formas de não dizer os regulamentos juninos não racializam as misses Mulata e Morena Cheirosa através de uma classificação racial explícita, mas sim por meio do subterfúgio de racializá-las musicalmente, proibindo-as de dançar coreografias mais voltadas ao campo das religiões de matriz africana. Por meio da música, da regulação da raça em performance, os regulamentos produzem a identidade "cabocla", vinculando-a não exatamente à raça, mas precisamente a atributos de etnicidade mediados pelo gênero e pela sexualidade. Fica-se diante de um debate no qual "a disputa quanto a se 'etnicidade' e 'raça' são fenômenos interligados ou se se referem a sistemas distintos de classificação social parece análoga aos enigmas sobre se as diferenças de sexo constituem a base natural a partir da qual se constroem as relações de gênero" (Stolcke 1991:107). Como bem demonstra Verena Stolcke (1991), a proposição sobre "se raça está para etnicidade assim como sexo estaria para gênero" é inviável. Mas é persistente no senso comum público.

Para finalizar este tópico, quero retornar brevemente às categorias de Miss Caipira e Miss Simpatia. Suas vinculações com gêneros musicais regionais (das regiões Norte ou Nordeste do Brasil) também remetem à formação étnica da Amazônia. O forró e o xaxado, indubitavelmente associados à Miss Caipira, atestam a influência nordestina na cultura amazônica. Ao analisar a formação da Amazônia do ponto de vista étnico e cultural, Vicente Salles (2005 [1971]) documentou - usando, muitas vezes, "raça" como correlata de "etnicidade" - aspectos da imigração nordestina para a Amazônia. ${ }^{26}$ Ao discorrer sobre os diversos "elementos étnicos" presentes no contexto amazônico, o autor concluiu que

a esses três elementos básicos de nossa etnia vieram reunir-se depois da Independência imigrantes estrangeiros de várias procedências e brasileiros do Nordeste, que foram antecedidos pelos contingentes maranhenses - e que só 
entre 1869 e 1870 somaram mais de cem mil indivíduos, numa época em que a população da Amazônia era calculada em cerca de 400 mil habitantes. O nordestino, que em algarismos passou a representar parcela tão considerável da população, não era o tipo étnico uniforme, como não era o maranhense, que o precedeu nesse movimento migratório de largas proporções: era massa humana heterogênea, com elevada percentagem de mestiços, mulatos e cabras, além de brancos e negros, que vieram toldar ainda mais o facies étnico e influir culturalmente (Salles 2005 [1971]:116).

Assim como o forró e o xaxado da Miss Caipira remetem à influência local dos nordestinos, o xote e o carimbó frequentemente dançados pela Miss Simpatia são indicações tanto da influência dos nordestinos quanto da presença cultural "cabocla" na quadra junina de Belém. Enfatizo mais uma vez que os regulamentos desses certames juninos operam com noções muito específicas de "raça" e "etnicidade", que aludem ao próprio processo histórico de formação racial, cultural e social das populações amazônicas. Com a composição das três categorias de miss - a Caipira, a Mulata e a Simpatia - temos três estratificações raciais que, respectivamente, expressam os resultados da miscigenação alusivos ao mito da democracia racial. Neste caso, a Miss Caipira é uma mulher "branca", embora não seja racialmente "pura", mas uma "nordestina" de pele "clara". A Miss Mulata é, por sua vez, a representante das populações "negras" que foram escravizadas no Brasil e que, pelas vias da sexualidade, foram sendo integradas ao projeto de nação. Por fim, a Miss Simpatia é associada às identidades étnico-raciais amazônicas de caráter mais híbrido, ora sendo considerada quase "branca", ora "indígena", ora "cabocla".

Contudo, os regulamentos atuais dos concursos juninos substituíram a categoria Miss Mulata pela designação Miss Morena Cheirosa. Esta alteração faz com que o caráter racialmente híbrido antes encenado somente pela Miss Simpatia seja agora performatizado também pela Miss Morena Cheirosa, numa tentativa de eliminar o componente "negro" e "africano" primeiramente associado à categoria Mulata. De todo modo, ainda que de maneira esmaecida, o mito da construção da nação a partir das três raças está presente nessas performances quadrilheiras. Situados nos domínios do ritual e da performance, os concursos juninos recuperam de modo artístico as ideias centrais presentes na ideologia do mito das três raças tratado por Roberto DaMatta como uma narrativa nacional que "permite ao homem comum, ao sábio e ao ideólogo conceber uma sociedade altamente dividida por hierarquizações como uma totalidade integrada por laços humanos dados com o sexo e os atributos 'raciais' complementares" (2010:77). O autor sublinha que o mito das três raças suaviza a divisão altamente hierárquica da 
sociedade brasileira no plano político e social, reposicionando os sujeitos num domínio supostamente unificado, que se materializa "nos ritos de Umbanda, na cordialidade, no carnaval, na comida, na beleza da mulher (e da mulata) e na música..." (2010:77). Sugiro que os concursos juninos, com suas três categorias de miss, aludem a esse discurso unificador que nega diferenças hierárquicas no Brasil e tenta perpetuar a falsa ideia da existência de uma democracia racial brasileira.

\section{Os silêncios dos regulamentos}

Através da análise da atuação das Fundações Culturais (especialmente a Fumbel) que, vinculadas aos poderes públicos, organizam e promovem os concursos oficiais da quadra junina de Belém, é possível perceber criticamente como o Estado produz certas regulações acerca dos significados do que sejam culturas populares. De modo reverso, através da resistência dos quadrilheiros ao poder normativo do estado, é possível também perceber como as culturas populares produzem o Estado. Assim, ressalto que as políticas culturais são sempre inconclusas, denotando o caráter inacabado do próprio Estado, entendido aqui como um estado-ideia nos termos de Abrams (1988). Um elemento demonstrativo do potencial de resistência dos quadrilheiros em face do estado é o fato de que, até hoje, a Fumbel não conseguiu implantar a eliminação das categorias de Miss Simpatia e Mulata/Morena Cheirosa dos concursos juninos, conforme admitiu Ruth Botelho. Também em depoimento anterior, esta gestora afirmou que até pouco tempo atrás a Fumbel não entendia que o gênero musical do carimbó pudesse integrar os concursos de miss, mas que essa compreensão mudou a partir de 2014, quando o carimbó foi incluído nos gêneros permitidos (e recomendados) para as misses. Destaco que essa nova compreensão da Fumbel não se deveu a uma iluminação espontânea, mas ao grande número de misses desclassificadas no certame de 2013 justamente por terem dançado o carimbó. Sendo assim, a fundação percebeu que os quadrilheiros admitem o carimbó como um gênero também relacionado ao período junino na Amazônia. Por isso, resolveu reconhecer como legítimas as performances deste gênero nos regulamentos dos anos subsequentes.

Fato semelhante ocorreu em 2016 com o dançarino Luan Branche, que havia coreografado uma Morena Cheirosa para dançar um gênero musical não compreendido como junino pelos jurados da Fumbel. Naquele ano, Luan, que também disputou concursos de Miss Gay como Lauanda Branche, dançou a mesma coreografia de sua candidata a Morena Cheirosa. Como 
Lauanda, foi desclassificada do certame porque a Fumbel entendeu que o gênero musical escolhido era incompatível com o período junino. Diante da desclassificação, Lauanda publicou em suas redes sociais: "E eu grito se for preciso. Fumbel a cada ano que passa desmoraliza nossa cultura e nosso trabalho. Eu quero é brilhantina pro meu cabelo marombado! Eu danço o que eu quero, não o que a Fumbel quer". Este tipo de ocorrência aponta para dois fatores: 1. muitas vezes é através das desclassificações nos certames que os quadrilheiros tomam conhecimento das concepções normativas que nem sempre estão explícitas nos regulamentos, mas que são idealizadas pelas Fundações Culturais e 2. a presença de relações conflituosas e de resistência entre quadrilheiros e as Fundações Culturais, ocasionando a reconstrução das políticas culturais do estado de modo dialógico.

Quero destacar ainda que, durante a pesquisa de maior escopo, consultei 26 regulamentos de certames e inúmeros outros documentos como, por exemplo, fichas de inscrição, mapas de apresentações de quadrilhas e misses, manuais de jurados e materiais de divulgação dos concursos juninos, especialmente banners veiculados nas redes sociais. O objetivo era entender melhor como as práticas performáticas são moldadas por todo esse aparato discursivo dos documentos consultados. A maior parte deles foi particularmente útil para compor minhas análises acerca das representações difundidas sobre a diversidade sexual e de gênero nos certames juninos de Belém (que não foram abordadas neste artigo, mas em texto anterior). ${ }^{27}$

Contudo, tendo em vista o recorte racial proposto para o presente texto, é possível perceber que quase nenhum conteúdo textual de quaisquer regulamentos foi aqui utilizado. Por diversos motivos, há um silêncio estrondoso nesses documentos quanto às questões raciais aqui abordadas porque elementos como raça e etnicidade não estão explicitamente prescritos nos regulamentos, mas implicitamente determinados pelas práticas e pelos discursos dos gestores que comandam as Fundações Culturais de Belém e do Pará. Essas prescrições normativas ecoam e surtem efeitos nas práticas e nos discursos dos produtores culturais das "periferias" de Belém, que também organizam seus certames juninos adotando ou rejeitando as regras propostas pelas Fundações Culturais do estado. Assim, os concursos das "periferias" são, simultaneamente, influenciados por e influenciadores dos concursos "oficiais" promovidos pelo estado.

Ao analisar os regulamentos que orientam os concursos juninos e os discursos que se constroem em torno desses documentos, compartilho das ideias postuladas por Adriana Vianna (2014) ao considerar que os documentos são "construtores da realidade", materializados como "atos no tempo" a partir de práticas discursivas que sedimentam condutas e sujeitos. Uma 
antropologia dedicada à etnografia de documentos deve estar alinhada à percepção de que esses artefatos discursivos são peças fundamentais para constituírem, hierarquizarem, segregarem e conectarem pessoas, conforme observam Laura Lowenkron e Letícia Ferreira (2014:83). ${ }^{28}$ Tentei apreender os significados daquilo que encontrei escrito nos regulamentos, observando como esses documentos produzem performances quadrilheiras e orientam a prática ritual dos certames juninos. Não obstante, encontrei lacunas e paradoxos que me fizeram notar os silêncios e as omissões neles contidos, atentando especialmente para o que eles não dizem de maneira explícita, mas colocam em prática de modo velado.

Perscrutando os usos e os discursos em torno das categorias Mulata e Morena Cheirosa nas festas juninas de Belém, considero que estas categorias falam acerca das interferências dos órgãos estatais e seus gestores culturais na produção de identidades étnico-raciais amazônicas. Além de atentar para os conteúdos textuais explícitos nos regulamentos juninos, observei especialmente os seus silêncios quanto a questões referentes à raça, etnicidade e sexualidade. Tais silêncios não representam ausência de prescrições normativas, mas significam que a regulação dos corpos, sujeitos e performances permanece oculta e impávida nas entrelinhas dos discursos dos gestores culturais que fomentam ações voltadas para as culturas populares.

Recebido em 10 de fevereiro de 2018

Aprovado em 08 de maio de 2018

Rafael da Silva Noleto é Professor Adjunto na Universidade Federal de Pelotas, atuando como docente no curso de Ciências Musicais nas áreas de Etnomusicologia, Antropologia, Musicologia e Estudos de Gênero e Sexualidade. Doutor em Antropologia Social (PPGAS/USP), possui interesses em Musicologia Popular e Antropologia da Performance, especialmente nas áreas de Música e Dança em sua interface com os Estudos de Gênero e Sexualidade. Contato: rafaeldasilvanoleto@gmail.com ORCID ID: http://orcid.org/0000-0003-3140-5062. 


\section{Notas}

1 Utilizo a categoria "certame" no sentido que a ela é atribuído pelo Dicionário UNESP do Português Contemporâneo, que a define como: 1. Campeonato; competição ou 2. concurso ou exposição artística. (Ver Borba 2004:265). Por se tratar de disputas nas quais está em jogo o ganho de um título de reconhecimento, considero a denominação adequada e a utilizo como sinônimo de "concurso". Optei pela alternância entre as duas categorias para evitar repetição excessiva de "concurso", que seria a categoria êmica mais utilizada pelos quadrilheiros. Contudo, a categoria "certame" é situacionalmente utilizada pelos gestores culturais do estado, tendo em vista que, em âmbito estatal, a ideia de "certame" implica a abertura de disputas a uma ampla concorrência de candidatos/as interessados/as em pleitear um prêmio, uma vaga de emprego no serviço público etc. A condução do processo desses "certames" deve obedecer aos princípios da administração pública. Porém, de forma intercambiável, a categoria "concurso" é também usada pelos gestores do estado como sinônimo de "certame". Em campo, ao utilizar tanto "concurso" quanto "certame", considero que me fiz entender pelos quadrilheiros e pelos gestores culturais, tendo em vista que ambos os grupos estão habituados a lidar de alguma forma com a linguagem corrente um do outro.

2 A perspectiva de marcadores sociais da diferença aqui adotada é signatária de um campo de discussões que, na contemporaneidade, problematiza a articulação entre gênero, classe social, geração, etnicidade, raça e sexualidade na produção de hierarquias entre sujeitos na esfera social. Indico a leitura de autoras feministas tais como Angela Davis (2016 [1981]), Gail Bederman (1996), Avtar Brah (2006 [1996]), Anne McClintock (2010 [1995]), Verena Stolcke (2006 [2003]), Adriana Piscitelli (2008) e Laura Moutinho (2014). Devido ao escopo do artigo, não discutirei em detalhes a produção cotidiana desses marcadores sociais nem o amplo campo teórico que estas autoras ajudaram a construir.

3 Entre os quadrilheiros, a Fundação Cultural do Estado do Pará (FCP) é comumente denominada como "Centur", em referência à antiga denominação de Centro Cultural e Turístico Tancredo Neves, nome que esta fundação cultural tinha quando foi criada na década de 1980. Por este motivo, a sigla que usarei neste artigo para fazer referência a esta fundação será "FCP/Centur".

4 Dentre os concursos que acompanhei nas "periferias", destaco os seguintes: "Rainha do São João" (Bairro do Jurunas - 2014, 2015 e 2016); "Concurso de Miss Caipira Gay da Tia Wal" (Bairro do Jurunas - 2014, 2015); "Rainha do São João na Pororoca" (Bairro da Sacramenta - 2014); "Miss Caipira Gay do Rancho" (Bairro do Jurunas - 2014, 2015 e 2016); "Concurso Melhor do Bairro" (Bairro do Benguí - 2014); "Concurso de Miss do Clube dos Comerciários (Município de Ananindeua, região metropolitana de Belém - 2014); Concurso de Ensaio de Quadrilhas do São Domingos ("Concurso de Sujo do São Domingos" - Bairro do Jurunas - 2014); Concurso de Ensaio da Quadrilha Tropicaliente ("Concurso de Sujo da Tropicaliente" - Bairro Cidade Nova IV, Ananindeua, região metropolitana de Belém) - 2014). Deve-se considerar que, em geral, os concursos juninos que 
ocorrem nas "periferias" duram de duas a três noites (quando são concursos de quadrilha) ou uma noite (quando se trata de concurso exclusivamente destinado às misses). Os concursos do estado e prefeitura, juntos, duram todo o mês de junho. Eu os acompanhei na totalidade de sua programação durante o tempo em que me dediquei ao trabalho de campo.

5 Os Cordões de Pássaro e de Bicho são grupos da cultura popular que dramatizam uma narrativa muito semelhante aos enredos do Boi-Bumbá. A trama central é desenvolvida a partir de um conjunto de acontecimentos relacionados à morte de um animal por um algoz, mais precisamente um caçador. Após a morte do bicho, que pode ser pássaro, boi ou outro animal, a história se desenrola a partir da obrigação, por algum forte motivo, de os personagens terem que conseguir a ressurreição do animal morto. Neste caso, somente um pajé, uma fada ou uma personagem que saiba lidar com poderes mágicos poderá resolver o impasse e ressuscitar o bicho.

6 A categoria "cisgênero" é usada para definir sujeitos que apresentam uma convergência entre o sexo biologicamente atribuído e a identidade de gênero socialmente vivenciada. É uma categoria de análise mobilizada como oposta a "transgênero", que define sujeitos cuja identidade de gênero diverge do sexo biologicamente atribuído. Para uma problematização das implicações do uso da categoria "cisgênero", ler Enke (2012) e Noleto (2017).

7 As Misses Gays têm um concurso em separado no qual se apresentam uma após a outra, sem a presença de nenhuma quadrilha. No entanto, ao serem anunciadas nos concursos, cada Miss Gay é designada como representante de determinada quadrilha. Muitas vezes isto pode significar que há um vínculo no qual o traje da miss é patrocinado ou emprestado pela quadrilha que está sendo representada por ela. Frequentemente, a Miss Gay é um brincante homossexual (ou transgênero) da quadrilha. Em alguns casos, a Miss Gay é o/a próprio/a coreógrafo/a da quadrilha ou das Misses Mulheres (Caipira, Mulata/Morena Cheirosa e Simpatia) que a compõem. Não abordarei com profundidade as diferenças entre as categorias de miss nem a atuação específica das Misses Gays/Mix no São João de Belém, pois já o fiz em textos anteriores. Ver Noleto (2014, 2016a, 2016b).

8 Para uma análise detalhada sobre os regulamentos que se referem às categorias Gay/Mix, ver Noleto (2016a).

9 Para consultas ao site oficial do Rancho, ver: http://rancho-pa.com/pa/. Acesso em 19/10/2016.

10 Para mais informações sobre a GLIC, consultar: http://www.fcp.pa.gov.br/. Acesso em 16/08/2016.

11 Os marcadores são mestres de cerimônia que conduzem toda a coreografia da quadrilha, fazendo a mediação do grupo coreográfico com o público presente e os jurados do certame.

12 Há quem diga que seria a maior procissão. Não tenho dados que possam confirmar esta informação. 
13 Para o conceito de "comunidades imaginadas", ver Benedict Anderson (2008 [1983]).

14 Por exemplo, na obra de Jorge Amado, a personagem Gabriela, mulher racialmente reconhecida sob o signo da miscigenação, possui cheiro de cravo e "cor" de canela, associando-se metonimicamente às ervas e aos temperos que usa para satisfazer a fome, mas também aos desejos sexuais dos homens de Ilhéus. Ainda na obra do mesmo autor, a personagem Dona Flor é definida como uma "morena rechonchuda servida de carnes", possuidora de "olhos de azeite" e de uma pele "cor" de chá. Sua relação com seus dois maridos e com a cidade de Salvador é inteiramente mediada pela comida que oferece a partir de seus dotes culinários. Na música, cito a obra de Ary Barroso. "Tabuleiro da baiana" e "Os quindins de Iaiá" são duas composições que mesclam a imagem racializada da mulher às comidas que serve em seu tabuleiro. As palavras (comidas) com sonoridade onomatopeica, como, por exemplo, "vatapá", "mugunzá", "caruru" e "quindins" são usadas para compor a rítmica sincopada do samba e, simultaneamente, fazer referência ao requebrado da morena brasileira. Em "Boneca de Piche", o compositor ainda compara os olhos da mulata à cor da jabuticaba, associando-a a uma fruta. Falando em frutas, é impossível não mencionar a contribuição emblemática (e cinematográfica) de Carmen Miranda para associar, no imaginário internacional, a figura sexualizada da mulher latino-americana aos sabores tropicais, representados por seus famosos chapéus com frutas (embora sua nacionalidade fosse portuguesa). Em Belém, o célebre compositor Waldemar Henrique em sua obra "Cantiga", cuja letra é de Manuel Bandeira, imagina que um corpo "moreno" desejado deve ter o travo e a cica dos cajus da praia. Mais contemporaneamente, no universo do funk carioca, muitas dançarinas deste gênero musical autodenominam-se "mulheres-fruta", associando seus supostos predicados sexuais (que interligam gênero e raça) a frutas como melancia, melão, maçã, morango etc.

15 Inspirado em McClintock e numa ampla bibliografia feminista, também elaborei uma reflexão acerca de como as nações são construídas em termos de sexualidade. Ver Noleto (2015).

16 A bibliografia socioantropológica é repleta de pensadores importantes que se dedicaram ao entendimento dos processos de construção da identidade nacional, dando enfoque especialmente às relações raciais. Destaco as obras de Gilberto Freyre (1998 [1933]), Florestan Fernandes (1972), Darcy Ribeiro (1995), Oracy Nogueira $(1998,2007)$ e Roberto DaMatta (2010). Mais adiante, problematizarei o que DaMatta chamou de "mito (ou fábula) das três raças", atentando para as implicações desse "mito" nos concursos de miss em Belém.

17 Anne McClintock (2010 [1995]) utiliza os conceitos de "tempo panóptico" e "espaço anacrônico" para problematizar como o discurso colonial aprisionou as colônias e seus sujeitos no reino do atavismo.

18 Os concursos juninos de Belém são divididos nas modalidades "adulta", "mirim" (ambas destinadas a certames de quadrilha e de misses) e "melhor idade" (destinada apenas às misses acima de 60 anos de idade). Realizei trabalho de campo em todas essas modalidades de concursos, entretanto, minha pesquisa foi circunscri- 
ta à categoria adulta devido à necessidade de realizar um recorte etnográfico mais preciso. Mas vale ressaltar que a modalidade mirim abarca candidatas de 07 a 14 anos e segue os mesmos moldes da modalidade adulta, tendo uma divisão tripartite das misses em "Caipira", "Mulata/Morena Cheirosa" e "Simpatia". Não há "Miss Gay" na modalidade "mirim", devendo as Misses Gays terem acima de 18 anos de idade. A modalidade melhor idade não é dividida em "Caipira", "Mulata/Morena Cheirosa" ou "Simpatia" e as exigências quanto ao desempenho das candidatas repousam mais sobre seu carisma diante do público do que propriamente sobre seus predicados em dança.

19 Dediquei-me à compreensão etnográfica das diferenças coreográficas e raciais entre as misses em Noleto (2016a).

20 Utilizo as respectivas classificações raciais entre aspas por compreender que toda e qualquer hierarquia social baseada em classificações de caráter racial é arbitrariamente engendrada de modo político, cultural, histórico e situacional. Isto significa que as classificações raciais são politicamente produzidas e não estão relacionadas a atributos específicos ditados pela biologia dos corpos.

21 Do ponto de vista da raça, o silêncio dos regulamentos juninos remete a uma etiqueta social no senso comum que evita a classificação racial explícita das pessoas no Brasil, especialmente se forem pessoas reconhecidas como "negras". Além disso, os concursos juninos não poderiam determinar, de modo excludente, características fenotípicas para as candidatas às categorias Mulata e/ou Morena Cheirosa, sob pena de arcar com as possíveis consequências legais deste tipo de discriminação. Entretanto, vale lembrar que no Brasil foi aprovada a Lei 12.990/2014, que institui a obrigatoriedade de cotas raciais nos concursos públicos federais. Esta lei estabelece que os/as candidatos/as "negros/as" ("pretos/as" ou "pardos/as") podem autodeclarar-se como tal para terem direito a concorrer à reserva de vagas. No intuito de evitar fraudes nos processos de autodeclaração, o Ministério do Planejamento, Desenvolvimento e Gestão (MPOG) publicou a Portaria n ${ }^{0}$ 4, de 06 de abril de 2018, que regulamenta o processo de heteroidentificação complementar à autodeclaração de candidatos/as negros/as. Nesse processo, uma banca examinadora seria encarregada de atestar a veracidade da autodeclaração racial dos/as candidatos/as. Se, por um lado, esse processo traz benefícios à população negra, por outro, a heteroidentificação possui implicações que remetem ao período do racismo científico, em que pessoas eram classificadas racialmente (e moralmente) com base em aferições antropométricas. A heteroidentificação acaba se transformando numa forma classificatória que passa a ter efeito de verdade, validando ou invalidando a autodeclaração e, por isso, manifestando-se como prática autoritária relacionada a certos pontos sensíveis do passado escravocrata do Brasil.

22 A noção de que há um entendimento espontâneo acerca de quais seriam as possíveis candidatas à categoria Mulata/Morena Cheirosa está baseada em elemento já identificado nos trabalhos clássicos de Oracy Nogueira $(1998,2007)$ : a classificação racial no Brasil se dá com base no fenótipo. Para o autor, as relações raciais no Brasil se sustentam em um "preconceito de marca", no qual as populações negras são estigmatizadas por suas aparências físicas, sotaques e práticas culturais. Assim, no contexto 
dos concursos juninos, há uma suposição tácita de que tanto os quadrilheiros quanto as Fundações Culturais sabem, com base nessa identificação da raça pelo fenótipo, quais são as candidatas que podem disputar o cargo de Mulata/Morena Cheirosa.

23 Mais adiante tentarei demonstrar como todas essas categorias de miss (e não apenas o par Mulata/Morena Cheirosa) atualizam o "mito das três raças" postulado por Roberto DaMatta (2010).

24 Essa compreensão da "mulata" advém de um vasto campo discursivo. Laura Moutinho (2004a), ao produzir uma revisão bibliográfica sobre o pensamento racial brasileiro, especialmente no que diz respeito à complexa interseção entre raça, gênero e sexualidade, condensou alguns pontos relevantes, presentes na produção teórica de alguns autores clássicos no campo da sociologia e da antropologia brasileiras. A autora sintetizou de forma provocadora os elementos discursivos utilizados por autores brasileiros (todos homens) para definir a mulata, estigmatizando-a, por consequência, tanto racialmente quanto sexualmente.

25 Para uma discussão mais detalhada sobre, respectivamente, concursos de beleza voltados para mulheres negras e cursos de profissionalização de mulatas no Rio de Janeiro, ver Giacomini (2006a, 1992, 2006b). Para um debate conceitual sobre a emergência da categoria mulata no imaginário nacional, ver Corrêa (1996). Para uma análise que problematize raízes históricas para as conexões entre raça e sexualidade no pensamento social brasileiro, ver Moutinho (2004a, 2004b).

26 Fábio Fonseca de Castro (2010:16) também documenta a intensa migração portuguesa e nordestina para Belém na transição entre os séculos XIX e XX.

27 Ver Noleto (2016a).

28 Para mais discussões acerca de etnografia de documentos, ler artigo de Letícia Ferreira (2013). Ver também Peirano (2006a, 2006b). 


\section{Referências bibliográficas}

ABRAMS, Philip. 1988. "Notes on the Difficulty of Studying the State". Journal of Historical Sociology, 01 (1): 58-89.

ANDERSON, Benedict. 2008 [1983]. Comunidades imaginadas: reflexões sobre a origem e difusão do nacionalismo. São Paulo: Companhia das Letras.

BEDERMAN, Gail. 1996. Manliness and civilization: race, gender and sexuality in the United States, 1880-1917. Chicago: Chicago Press.

BORBA, Francisco S. (org). 2004. Dicionário UNESP do Português Contemporâneo. São Paulo: Unesp.

BRAH, Avtar. 2006 [1996]. "Diferença, diversidade, diferenciação". Cadernos Pagu, 26: 329-376, jul.-dez.

CASTRO, Fábio Fonseca de. 2010. A Cidade Sebastiana: era da borracha, memória e melancolia numa capital da periferia da modernidade. Belém: Edições do Autor.

2013. "A identidade denegada. Discutindo as representações e a autorrepresentação dos caboclos das Amazônia". Revista de Antropologia, 56 (2):431-475.

CHIANCA, Luciana. 2006. A festa do interior: São João, migração e nostalgia em Natal no século XX. Natal: Editora da UFRN.

. 2013a. São João na cidade: ensaios

e improvisos sobre a festa junina. João Pessoa: UFPB. . 2013b. "O auxílio luxuoso da sanfona: tradição, espetáculo e mídia nos concursos de quadrilhas juninas". Revista Observatório Itaú Cultural, n. 14:89-100.

CORRÊA, Mariza. 1996. "Sobre a invenção da mulata". Cadernos Pagu, 6-7:35-50.

DAMATTA, Roberto. 2010. Relativizando: uma introdução à antropologia social. Rio de Janeiro: Rocco.
DAVIS, Angela. 2016 [1981]. Mulheres, raça e classe. São Paulo: Boitempo Editorial.

ENKE, Anne Finn. 2012. The Education of Little Cis: Cisgender and the Discipline of Opposing Bodies. In:

(ed.), Transfeminist perspectives: in and beyond transgender and gender studies. Philadelphia, Pensilvania: Temple University Press. pp. 60-77.

FERNANDES, Florestan. 1972. O negro no mundo dos brancos. São Paulo: Difusão Europeia do Livro.

FERREIRA, Letícia. 2013. "'Apenas preencher papel': reflexões sobre registros policiais de desaparecimento de pessoa e outros documentos". Mana 19 (1):39-68.

FREYRE, Gilberto. 1998 [1933]. Casa-grande \& senzala. Rio de Janeiro: Record.

GIACOMINI, Sonia Maria. 1992. Profissão mulata: natureza e aprendizagem num curso de formação. Dissertação de Mestrado, Universidade Federal do Rio de Janeiro. 1994. "Beleza Mulata e Beleza Negra". Estudos Feministas, Número Especial (n.e): 217-227.

. 2006a. A alma da festa: família, etnicidade e projetos num clube social da Zona Norte do Rio de Janeiro: o Renascença Clube. Belo Horizonte/ Rio de Janeiro: Editora UFMG/ IUPERJ. . 2006b. "Mulatas profissionais: raça, gênero e ocupação". Estudos Feministas, 14 (1):85-101.

GUZMÁN, Décio de Alencar. 2006. "Índios misturados, caboclos e curibocas: análise histórica de um processo de mestiçagem, Rio Negro (Brasil), séculos XVII e XIX". In: C. Adams; R. Nurrieta \& W. Neves (orgs.), Sociedades caboclas amazônicas: 
modernidade e invisibilidade. São Paulo: Annablume. pp. 67-80.

LEAL, Eleonora. 2004. Contando o tempo: a evolução coreográfica das quadrilhas juninas em Belém do Pará. Dissertação de Mestrado, Universidade Federal da Bahia. . 2011. "Contando o tempo: a quadrilha moderna dos anos 80". Ensaio Geral, 5 (3):51-64.

LOWENKRON, Laura \& FERREIRA, Letícia. 2014. "Anthropological perspectives on documents: ethnographic dialogues on the trail of police papers". Vibrant, 11 (2):76-112.

MCCLINTOCK, Anne. 2010 [1995]. Couro imperial: raça, gênero e sexualidade no embate colonial. Campinas: Unicamp.

MENEZES NETO, Hugo. 2008. O balancê no Arraial da Capital: quadrilha e tradição no São João do Recife. Dissertação de Mestrado, Universidade Federal de Pernambuco.

. 2015. "Música e festa na perspectiva das quadrilhas juninas de Recife". Anthropológicas, 26 (1):103-133.

MOTTA, Roberto. 2000. Paradigmas de interpretações das relações raciais no Brasil. Estudos Afro-Asiáticos, 38. DOI: http://dx.doi.org/10.1590/ S0101-546X2000000200006.

MOUTINHO, Laura. 2004a. Razão, "Cor" e desejo: uma análise comparativa sobre relacionamentos afetivo-sexuais "inter-raciais" no Brasil e na África do Sul. São Paulo: Editora Unesp. . 2004b. "'Raça', sexualidade e gênero na construção da identidade nacional: uma comparação entre Brasil e África do Sul". Cadernos Pagu, 23 (2):55-88.

. 2014. "Diferenças e desigualdades negociadas: raça, sexualidade e gênero em produções acadêmicas recentes". Cadernos Pagu, 42 (1):201-248.
NÓBREGA, Zulmira. 2010. A festa do maior São João do mundo: dimensões culturais da festa junina na cidade de Campina Grande. Tese de Doutorado, Universidade Federal da Bahia. . 2012. "A festa do maior São João do mundo". In: L. Rubim \& N. Miranda (orgs.), Estudos da festa. Salvador: Edufba. pp. 217-242.

NOGUEIRA, Oracy. 1998. Preconceito de marca: as relações raciais em Itapetininga. São Paulo: Edusp. . 2007. "Preconceito racial de marca e preconceito racial de origem: sugestão de um quadro de referência para a interpretação do material sobre relações raciais no Brasil". Tempo Social, 19 (1):287-308.

NOLETO, Rafael da Silva. 2014. "'Brilham estrelas de São João!': notas sobre os concursos de 'Miss Caipira Gay' e 'Miss Caipira Mix' em Belém (PA)". Sexualidad, salud y sociedadRevista latino-americana, 18: 74-110. . 2015. Comunidades sexualizadas: articulando raça, gênero e sexualidade na construção de nações. In: C.D. Cancela; L. Moutinho \& J. Simões (orgs.), Raça, etnicidade, sexualidade e gênero em perspectiva comparada. São Paulo: Terceiro Nome. pp. 121-141. . 2016a. Brilham estrelas de São João: gênero, raça e sexualidade em performance nas festas juninas de Belém - PA. Tese de Doutorado, Universidade de São Paulo. . 2016b. "'Babados, xotes e xaxados': notas sobre festa, ritual e marcadores sociais da diferença na quadra junina de Belém". Amazônica: Revista de Antropologia, 8 (1):198-221.

. 2017. "Casamento em performance, parentesco em questão: gênero e sexualidade no São João de Belém, Pará". Cadernos Pagu, 51: DOI http:// dx.doi.org/10.1590/1809444920170 0510020 . 
PEIRANO, Mariza. 2006a. "'Sem lenço, sem documento': cidadania no Brasil". In: , A teoria vivida e outros ensaios de antropologia. Rio de Janeiro: Jorge Zahar Editor. pp. 121-134. . 2006b. "A lógica múltipla dos documentos". In: A teoria vivida e outros ensaios de antropologia. Rio de Janeiro: Jorge Zahar Editor. pp 135-153.

PISCITELLI, Adriana. 2008. "Interseccionalidades, categorias de articulação e experiências de migrantes brasileiras". Sociedade e cultura, 11 (2):263-274.

RIBEIRO, Darcy. 1995. O povo brasileiro: evolução e o sentido do Brasil. São Paulo: Companhia das Letras.

RODRIGUES, Carmen Izabel. 2006. "Caboclos na Amazônia: a identidade na diferença". Novos Cadernos NAEA, 9 (1):119-130.

SALLES, Vicente. 2005 [1971]. O negro no Pará sob regime de escravidão. Belém: IAP.

SILVEIRA, Flávio Leonel Abreu da; MOUTINHO, Laura \& SOUZA, Camilla da Silva. 2015. "Nos manguezais, desejos e paisagens se confundem: o real e o fantástico entre coletores de caranguejo em Bragança (PA)". In: C.D. Cancela; L. Moutinho \& J. Simões (orgs.), Raça, etnicidade, sexualidade e gênero em perspectiva comparada. São Paulo: Terceiro Nome. pp. 23-38.

SOUZA LIMA, Antonio Carlos de. 2012. "Apresentação. Dossiê Fazendo Estado". Revista de Antropologia, 55 (2):559-564.

STOLCKE, Verena. 1991. "Sexo está para gênero assim como raça para etnicidade?". Estudos Afro-Asiáticos, 20:101-119. . 2006 [2003]. "O enigma das interseções: classe, 'raça', sexo, sexualidade. A formação dos impérios transatlânticos do século XVI ao XIX". Estudos feministas, 14 (1):15-42.

VIANNA, Adriana. 2014. "Etnografando documentos: uma antropóloga em meio a processos judiciais". In: S. Castilho; A.C.S. Lima \& C. Teixeira (orgs.), Antropologia das práticas de poder: reflexóes etnográficas entre burocratas, elites e corporações. Rio de Janeiro: Contra Capa. pp. 43-70.

\section{Regulamentos e documentos mencionados no artigo}

FCP. 2015. Regulamento Geral do Arraial de Todos os Santos/2015. XII Concurso Estadual de quadrilhas juninas. Categorias: adultas, mirins e miss.
FUMBEL. 2014. Regulamento Geral do Concurso de Misses Juninas Adultas e Mirins. 
COR DE JAMBO E OUTROS MATIZES

DA MULATA E O ADVENTO DA

MORENA CHEIROSA NAS FESTAS

JUNINAS DE BELÉM
AMAZÔNICOS: SOBRE A ABOLIÇÃO

\section{JAMBO COLOUR AND OTHER \\ AMAZONIAN HUES: ON THE ABOLITION OF THE MULATA AND \\ THE ADVENT OF THE MORENA CHEIROSA AT THE JUNE FESTIVALS OF BELÉM}

\section{Resumo}

Neste texto, busco pensar na atuação consciente do Estado ao produzir categorias sociais que sexualizam a raça e racializam o gênero nas políticas públicas para a promoção das culturas populares. Perscrutando os usos e os discursos em torno das categorias Miss Mulata e Miss Morena Cheirosa nas festas juninas de Belém, argumento que essas categorias falam acerca das interferências dos órgãos estatais e seus gestores culturais na produção de identidades étnicoraciais amazônicas. Além de atentar para os conteúdos textuais explícitos nos regulamentos dos concursos juninos, observo especialmente os seus silêncios quanto a questões referentes à raça, etnicidade e sexualidade. Tais silêncios não representam ausência de prescrições normativas, mas significam que a regulação dos corpos, sujeitos e performances permanece oculta nas entrelinhas dos discursos dos gestores culturais que fomentam ações voltadas para as culturas populares.

Palavras-chave: Raça, Etnicidade, Cultura popular, São João, Documentos.

\begin{abstract}
In this article, I consider the state's conscious production of social categories that sexualize race and racialize gender in public policies in order to promote popular cultures. Looking at the practices and discourses surrounding the categories "Miss Mulata" and "Miss Morena Cheirosa" at the June festivals in Belém, I argue that these categories reveal the interference of state organs and their cultural brokers in the production of Amazonian ethnic-racial identities. In addition to looking at the explicit textual content of the regulations of the June contests, I note what the omit regarding issues of race, ethnicity and sexuality. Such omissions do not reflect a lack of normative prescriptions, but mean that the regulation of bodies, subjects, and performances remains hidden and immobile in the interstices of the discourse of cultural brokers who foster policies geared toward popular cultures. Keywords: Race, Ethnicity, Popular Cultures, June Festivals, Documents.
\end{abstract}




\title{
COLOR DE YAMBO Y OTROS \\ MATICES AMAZÓNICOS: \\ SOBRE LA ABOLICIÓN DE LA \\ MULATA Y LA LLEGADA DE LA \\ MORENA CHEIROSA EN LAS \\ FIESTAS DE JUNIO EN BELÉM
}

\begin{abstract}
Resumen
En este texto, busco pensar la actuación consciente del Estado al producir categorías sociales que sexualizan la raza y racializan el género en las políticas públicas para la promoción de las culturas populares. Investigando los usos y discursos en torno a las categorías Miss Mulata y Miss Morena Cheirosa en las fiestas juninas de Belém, argumento que esas categorías dejan en evidencia las interferencias de los órganos estatales y sus gestores culturales en la producción de identidades étnicoraciales amazónicas. Además de notar los contenidos textuales explícitos en los reglamentos de los concursos juninos, observo especialmente sus silencios en cuanto a cuestiones de raza, etnicidad y sexualidad. Tales silencios no representan ausencia de prescripciones normativas, sino que significan que la regulación de los cuerpos, sujetos y performances permanece oculta en las entrelíneas de los discursos de los gestores culturales que fomentan acciones dirigidas a las culturas populares.
\end{abstract}

Palabras clave: Raza, Etnicidad, Cultura Popular, San Juan, Documentos. 